\title{
A külföldi tulajdonú vállalatok és az import szerepe a hazai térségek exportjának diverzifikációjában
}

Ebben a tanulmányban a külföldi tulajdonú vállalatok és az import szerepét vizsgáljuk 75 hazai kistérség feldolgozóipari exportszerkezetének időbeli változásában 2000 és 2011 között. Az egyes küllkereskedelmi termékek előállításához szükséges képességbázis hasonlóságát hálózatelemzésen alapuló módszerrel mérjuik. A tanulmány eredményei szerint a hazai térségek exportszerkezetének megváltozására hatással van a már meglévő export-, illetve importszerkezet, valamint a kapcsolódó termékek jelenléte. Az exportszerkezet stabilitásához különösen a hazai vállalatok által előállított kapcsolódó exporttermékek járulnak hozzá. Az új exporttermékek megjelenését a külföldi és a hazai vállalatok exportja esetében is segíti a másik kapcsolódó termékeinek jelenléte. Az exporthoz kapcsolódó import szintén föleg a térségek számára új exporttermékek megjelenésénél játszik szerepet. Végül a hazai vállalatok kapcsolódó importjának sürüsége a külföldi vállalatok által termelt új exporttermékek megjelenését is elősegíti. Journal of Economic Literature (JEL) kód: F21, O18, R0, R11.

\section{Bevezetés}

A régiók ${ }^{1}$ gazdasági szerkezetének időbeli változása a szakirodalomban és a szakpolitikában egyaránt számottevő figyelmet kap, mivel e szerkezet megújulásának képessége a térségek hosszú távú versenyképességének fontos hajtóereje. Számos kutatási

* Köszönettel tartozunk Jakobi Ákosnak és Sebestyén Tamásnak, akik a tanulmány alapjául szolgáló doktori értekezés bírálóiként értékes tanácsokkal járultak hozzá a tanulmány létrejöttéhez. A kutatást az EFOP-3.6.2-16-[2017-00007 azonosítószámú, Az intelligens, fenntartható és inkluzív társadalom fejlesztésének aspektusai: társadalmi, technológiai, innovációs hálózatok a foglalkoztatásban és a digitális gazdaságban című projekt támogatta. A projekt az Európai Unió támogatásával, az Európai Szociális Alap és Magyarország költségvetése társfinanszírozásában valósul meg.

${ }^{1}$ A tanulmányban a régió és a térség szavakat azonos jelentéstartalommal használjuk. Mindkét kifejezés szubnacionális területi egységet jelent, amely csomóponti régiónak tekinthető. Az operacionalizáció során ezeket a térségeket a kistérségi területi szinttel azonosítjuk.

Elekes Zoltán, KRTK KTI Agglomeráció és Társadalmi Kapcsolathálózatok Lendület Kutatócsoport,

Umeå Universitet, Szegedi Tudományegyetem (e-mail: elekes.zoltan@krtk.mta.hu).

Lengyel Balázs, KRTK KTI Agglomeráció és Társadalmi Kapcsolathálózatok Lendület Kutatócsoport,

Budapesti Corvinus Egyetem, International Business School Budapest.

A kézirat első változata 2019. december 13-án érkezett szerkesztőségünkbe.

DOI: http://dx.doi.org/10.18414/KSZ.2020.4.352 
eredmény támasztja alá, hogy a térségekben már jelen lévő gazdasági tevékenységek köre befolyásolja a jövőben megjelenő, illetve eltűnő tevékenységek körét (Hidalgo és szerzötársai [2007], Neffke és szerzőtársai [2011], Boschma és szerzőtársai [2013]). Ennek a kapcsolódó diverzifikációs (related diversification) folyamatnak a hátterében az áll, hogy az egyes gazdasági tevékenységek csak részben átfedö, helyben elérhetö képességek (capabilities) meglétét feltételezik. E képességek körébe ugyanúgy beletartoznak a fizikai infrastruktúra elemei, mint a helyben jellemző intézmények, normák, szakértelem, illetve hálózatok (Hidalgo és szerzőtársai [2007]). A térségek diverzifikációja ilyen módon a helyi képességbázis újrakombinálásának folyamata.

Jóval kevesebb ismerettel rendelkezünk azonban arról, hogy a régión kívül hozzáférhető képességek becsatornázása hogyan befolyásolja a regionális diverzifikációt. Vannak arra mutató eredmények, hogy az exporthoz kapcsolódó import hatással van az országok exportdiverzifikációjára (Boschma-Capone [2016]), illetve hogy a nem helyi szereplők (régión kívüli vállalat új telephelye, külföldi tulajdonú vállalatok) gyakrabban valósítanak meg kevésbé kapcsolódó diverzifikációt (Neffke és szerzőtársai [2018], Elekes és szerzőtársai [2019]). Az azonban, hogy ezek a régión kívüli képességek milyen szisztematikus hatást gyakorolnak a régiók diverzifikációs folyamatára, kevésbé tisztázott. E tanulmány célja éppen ezért a külföldi tulajdonú vállalatok és az import csatornáin keresztül a régión kívül hozzáférhető képességek szerepének feltérképezése a hazai térségek exportdiverzifikációjában. Ehhez a KSH által biztosított vállalati szintű paneladatbázisra, illetve a Massachusetts Institute of Technologynek a The Observatory of Economic Complexity elnevezésű projektje keretében nyilvánossá tett, országok közötti kereskedelmi termékáramlásokat tartalmazó adatbázisra támaszkodunk. A két adatforrás segítségével megmérjük az egyes külkereskedelmi termékek előállításához szükséges képességbázis hasonlóságát, majd ennek segítségével elemezzük a kapcsolódó termékek jelenléte és a feldolgozóipari exportszerkezet megváltozása közötti kapcsolatot 75 hazai kistérség esetében 2000 és 2011 között.

Ezzel a munkával kétféle módon szeretnénk hozzájárulni a szakirodalomhoz. Egyrészt az evolúciós gazdaságföldrajzi szakirodalom számára újdonságértékü eredményeket közlünk a külföldi tulajdonú vállalatok, illetve az import kapcsolódó diverzifikációban betöltött szerepéröl. Másrészt a tágabb hazai regionális gazdaságtani szakirodalomhoz járulunk hozzá azáltal, hogy a más országok térségeiben dokumentált kapcsolódó diverzifikációs mintázatot hazai adatok segítségével mutatjuk meg, amely így a korábbi eredmények külső érvényességét támasztja alá. A hazai regionális gazdaságfejlesztési szakpolitika számára pedig a hazai adatokon végzett vizsgálatnak van különös fontossága.

A tanulmány legfontosabb eredményei szerint a hazai térségek exportszerkezetének időbeli változására hatással van a már meglévő export-, illetve importszerkezet, a kapcsolódó termékek jelenléte. Az exportszerkezet stabilitásához különösen a hazai vállalatok által előállított exporttermékek sürüsége járul hozzá. Az új exporttermékek megjelenését a külföldi és a hazai vállalatok által létrehozott export esetében is segíti, ha léteznek már más kapcsolódó termékeik is. Végül az exporthoz kapcsolódó import szintén föleg az új termékek megjelenésénél játszik szerepet. Lényeges, hogy 
a hazai vállalatok kapcsolódó importjának sűrüsége segíti az egyes régiókban a külföldi vállalatok által termelt új exporttermékek megjelenését is.

A tanulmány a következőképpen épül fel. A bevezetést követő részben a regionális diverzifikációval és a régión kívül hozzáférhető képességekkel kapcsolatos szakirodalomban helyezzük el a kutatást. Ezt követően bemutatjuk az elemzés alapjául szolgáló adatokat, a termékek közötti technológiai közelség és regionális terméksürüség mérési módszerét, valamint a választott ökonometriai modellt. A tanulmány az eredmények ismertetését követően összegzéssel zárul.

\section{A kapcsolódó diverzifikáció}

A közgazdászokat régóta foglalkoztatja, hogy vajon miért vannak olyan vállalatok, amelyek több, esetenként eltérö iparágra jellemző terméket állítanak elö egyszerre, illetve mivel magyarázható a vállalati termékportfólió időbeli változása (Lőrincz és szerzötársai [2019]).

A többtermékes vállalatok eröforrás-alapú megközelítése azt hangsúlyozza, hogy diverzifikáció révén hatékonyságnövelésre lehet fordítani a termelésben felhasznált erőforrások oszthatatlanságából fakadóan kihasználatlan kapacitást. Ezek az erőforrások azonban gyakran erősen tevékenységhez kötöttek a termelési folyamatban betöltött szerepük miatt, ezért csak a termelőtevékenységek szűk körében alkalmazhatók, ami szükíti a diverzifikációs lehetőségek körét (Penrose [1959]). Ahogy a vállalatok egyre hatékonyabban használják egyes erőforrásaikat, úgy válnak egyre kihasználatlanabbá más erőforrásaik, ami a meglévőkhöz kapcsolódó használati módok keresésére, kapcsolódó diverzifikációra ösztönzi a vállalatokat (Teece [1982]). Az értékes, ritka, nehezen másolható és nehezen helyettesíthető erőforrások tartós versenyelönyt biztosítanak a vállalatok számára (Barney [1991]). Végül a hosszú távú fennmaradás érdekében a vállalatoknak dinamikus képességeiken (dynamic capabilities) keresztül időről időre meg kell újítaniuk az erőforrásbázisukat (Teece és szerzőtársai [1997]). Ilyen értelemben a vállalatok tartós versenyelőnye azon múlik, hogy a rendelkezésükre álló képességbázist mennyire sikeresen tudják kihasználni, illetve megújítani a külső körülmények változása esetén. A képességek a termelési tényezőkből, a rendelkezésre álló, nehezen másolható és immobil erőforrásokból, a szervezeti rutinokból és kompetenciákból emelkednek ki (Teece és szerzőtársai [1997]).

A képességek kihasználása és kombinálása szempontjából lényeges a térbeliség dimenziója, amely strukturálja a társadalmi kapcsolatokat (Jakobi-Lengyel [2014], Lengyel-Jakobi [2016]). A vállalatok közötti munkaerő- és információáramlásnak (Arzaghi-Henderson [2008], Neffke-Henning [2013]), az üzleti és tudáshálózatokban való részvételnek (Sebestyén-Varga [2013], Kondor és szerzőtársai [2014], GyurkovicsVas [2016], Juhász [2019], Varga és szerzőtársai [2020]), illetve a korábbi szervezetböl kiváló, „kipörgetett” (spin-off) vállaltok létrejöttének (Klepper [2007]) egyaránt erös a helyi kötődésük.

A képességeket tekinthetjük olyan termelö inputoknak, amelyekkel nem lehet a nemzetközi kereskedelemben kereskedni (Hidalgo és szerzőtársai [2007]). Ha 
lehetne, akkor a vállalatok megszerezhetnék azokat, és a hiányuk nem befolyásolná az országok lehetőségét új iparágak kialakítására. Ezek a képességek lehetnek konkrét infrastrukturális elemek, helyben hozzáférhető szakértelem, intézmények és normák is. A helyi képességbázis (local capability base) a helyi erőforrásokból emelkedik ki, fenntartja a helyben jelen lévő - több vállalat által is használható - gazdasági tevékenységeket, és elsősorban a régión belülről lehet hozzáférni (Neffke és szerzötársai [2018]). Az egyes vállalatok termelési tevékenységük során kombinálják ezeket az erőforrásokat és képességeket (Lawson [1999]).

A régiók diverzifikációjával kapcsolatban az az alapvető kérdés, hogy vajon a térségek meglévő képességbázisa hogyan befolyásolja az új tevékenységek megjelenésének lehetőségét. Egyre bővülő empirikus szakirodalom alapján az tűnik általános érvényünek, hogy az egyes térségekben olyan tevékenységek jelennek meg, amelyek kapcsolódnak a már jelenlévőkhöz, illetve a kevésbé kapcsolódó tevékenységek nagyobb valószínűséggel tűnnek el (lásd Elekes [2016] áttekintését). Magyarország szempontjából lényeges, hogy egyrészt a kevésbé fejlett gazdaságokban jellemzőbb a kapcsolódó diverzifikáció, mint a nem kapcsolódó, vagyis az újonnan megjelenő exporttermékek szorosabban kapcsolódnak a meglévő portfólióhoz (BoschmaCapone [2016]). Másrészt a koordinált piacgazdaságokban inkább jellemző az erösebb technológiai közelségben lévő termékek szerinti diverzifikáció, mint a liberális piacgazdaságok esetében (Boschma-Capone [2015]).

Lényeges kérdés azonban, hogy a régión kívülről „kölcsönvett” képességek segítségével a régió számára kedvezően befolyásolható-e a diverzifikáció. A régión kívüli képességekhez való hozzáférés eszköze lehet-e a helyben meglévő képességek alapján nem megvalósítható termelési szerkezetek elérésének, illetve a régiók közötti jelentős termelésbeli különbségek mérséklésének? Ebben a kutatásban két ilyen csatornát, az importot és a külföldi tulajdonú vállalatok jelenlétét vizsgáljuk.

A magyar gazdaságra jellemző, hogy a termeléshez szükséges termelési tényezők, köztes termékek számottevő hányada import (Halpern és szerzőtársai [2015]), illetve a sikeres exportjelenlét gyakran jelentős importartalommal jár együtt (Békés és szerzőtársai [2013]). Éppen ezért az import fontos csatornája lehet a régión kívüli képességekhez való hozzáférésnek. Boschma-Iammarino [2009] Olaszország térségei esetében azt találta, hogy az import változatossága elsősorban akkor hat kedvezően a regionális foglalkoztatottság növekedésére, ha kapcsolódik a már jelen lévő exporttevékenységekhez, azaz az import által becsatornázott képességeket a helyben működő vállalatok legalább részben képesek kombinálni a helyi képességbázissal. Országok esetében a szerzőpáros azt is dokumentálta, hogy az exporthoz kapcsolódó import az új exporttermékek megjelenését és azok fennmaradását egyaránt segíti (Boschma-Capone [2016]).

A külföldi tulajdonú vállalatok szerepének vizsgálata a regionális diverzifikációban szintén lényeges, mert a világgazdasági termelés jelentős és egyre növekvő részét teszik ki ezeknek a vállalatoknak a termékei (Iammarino-McCann [2013]). A külföldi tulajdonú vállalatok képesek hozzáférni a vállalat számára belső, de a régió számára külső képességekhez, amelyeket a vállalatcsoporti hálózatokon keresztül tudnak becsatornázni (Almeida [1996], Cantwell-Piscitello [2005], Alcácer-Chung [2007]). Arról 
viszont kevesebbet tudunk, hogy a külföldi tulajdonú vállalatok jelenléte milyen szisztematikus hatást gyakorol a helyi gazdaság szerkezetének átalakulására.

Magyarországon, hasonlóan más kelet-közép-európai gazdaságokhoz, a külföldi tulajdonú vállalatok jelenős szerepet játszottak a gazdasági szerkezet alakulásában (Radosevic [2002], Resmini [2007], Nölke-Vliegenthart [2009]). A gazdasági átmenet egyszersmind a nemzetközi versenynek való hirtelen kitettséget is jelentett (Rodrik [1992]), a 2000 -es évekre pedig a magyar gazdaságban kialakult a külföldi tulajdonú és hazai vállalatok dualitása (Szanyi [2010]), ahol a kisebb számú külföldi tulajdonú vállalat, különösen az export esetében, jóval nagyobb gazdasági teljesítményt állít elö, mint a nagyszámú hazai vállalat. A hazai régiók nemzetközi kereskedelmének jelentős része - különösen a feldolgozóipar esetében - a külföldi tulajdonú vállalatoknak tulajdonítható, továbbá ezek a vállalatok az exportnövekedés motorjai (Benacek és szerzőtársai [2000], Sass [2003]). Ezenfelül a külföldi tulajdonú vállalatok a hazaiaknál hatékonyabban használják fel az importált termelési tényezőket is (Halpern és szerzőtársai [2015]). A szabadalmakkal mért tudástermelést Kelet-Közép-Európában szintén a külföldi tulajdonú vállalatok uralják (Lengyel B. és szerzőtársai [2015]).

E szakadék ellenére termelékenységi túlcsordulások (spillover) mutathatók ki a külföldi tulajdonú és a hazai vállalatok között (Csáfordi és szerzőtársai [2020]), amelyek erőssége a távolság növekedésével csökken (Halpern-Muraközy [2007]). A külföldi tulajdonú és hazai vállalatok közötti túlcsordulások horizontálisan, közvetlen input-output kapcsolat nélkül, és vertikálisan, a külföldi tulajdonúakhoz értékláncban kapcsolódva, tanuláson keresztül is megvalósulhatnak (PavlínekŽižalová [2016]). A külpiacra lépés különösen a kis- és közepes méretü vállalatok esetében jelentős erőfeszítést igényelhet (Antalóczy-Sass [2011]), amelyben a külföldi tulajdonú vállalatok értékláncaihoz kapcsolódás segítséget jelenthet. Jellemzően azok a hazai vállalatok lehetnek felkészültebbek a külföldi tulajdonú vállalatok jelenlétéből származó előnyök kiaknázására, amelyek termelékenyebbek, így abszorpciós kapacitásuk magasabb (Békés és szerzőtársai [2009]). Ezek az előnyök mások mellett a megnövekedett emberi tőkében, fejlettebb menedzsmenteljárásokban, rutinokban és technológiákban ölthetnek testet. A hazai vállalatok általánosságban kevésbé innovatívak (Halpern-Muraközy [2010]), a külföldi tulajdonú vállalatok pedig kevésbé beágyazottak a helyi termelési láncokba (Barta [2005]).

A külföldi tulajdonú vállalatok elősegíthetik, hogy a hazai vállalatok növelhessék diverzifikációjukat, termelésükben nagyobb súllyal szerepeljenek a komplexebb termékek (Békés és szerzőtársai [2009], Javorcik és szerzőtársai [2018]). Ezek a vállalatok jellemzően a befogadó gazdaság vállalatai számára csatlakozási pontot jelentenek a nemzetközi értékláncokhoz. Ennek viszont gyakran elöfeltétele a hazai vállalatok termelésben való feljebb lépése, jobb minőségű köztes termékek elóállítása (Békés-Muraközy [2016]), amely így a beszállítóvá válás alapja lehet (Antalóczy [2012]). A külföldi tulajdonú vállalatok erősebben kapcsolódnak a nemzetközi értékláncokhoz, míg a helyi vállalatok jobban ismerik a helyben hozzáférhető képességbázist, könnyebben férnek hozzá, és beágyazottabbak a régió gazdaságába (Neffke és szerzötársai [2018]). 


\section{Empirikus kutatás}

\section{Adatbázis és mintavétel}

Ebben a kutatásban két adatforrásra támaszkodunk. Az egyik a KSH által biztosított vállalati szintü paneladatbázis, amely a kettős könyvvitelt végzö, Magyarország területén működő vállalatokra vonatkozóan tartalmaz adatokat. Az adatbázis információt nyújt a vállalatok székhelyéröl, amennyiben folytatnak nemzetközi kereskedelmi tevékenységet, akkor ezeknek a termékáramlásoknak a pénzbeli értékéről és arról, hogy mely 4 jegyü SITC termékkódok vonatkoznak rájuk. A termékáramlások értékét a KSH által közzétett termékcsoporti árindexek segítségével 2000-es szintre számítottuk át. Ismerjük azt is, hogy a vállalatok jegyzett tőkéjének hány százaléka van külföldi tulajdonban, ami alapján egy vállalatot egy évben akkor tekintünk külföldi tulajdonúnak, ha jegyzett tőkéje 50 százalék felett külföldi tulajdonban van. Mivel székhelyre vonatkozó adatok állnak rendelkezésünkre, az adatbázist a feldolgozóipari vállalatok részmintájára szűkítjük. Az adatok megbízhatósága érdekében azokat a vállalatokat vesszük figyelembe, amelyek a vizsgált időszakban legalább két főt foglalkoztattak. Az elemzésünk területi egysége a kistérség, amelyek közül azokat vizsgáljuk, amelyekben a nemzetközi kereskedelem minimálisan jelen van, vagyis legalább két hazai és külföldi tulajdonú vállalat folytatott külkereskedelmet a vizsgált időszakban. Így a régiós mintába 75 kistérség kerül, amelyek diverzifikációs mintázatát termék-régió kombinációk szintjén 2000 és 2011 között vizsgáljuk.

A másik felhasznált adatbázis az MIT The Observatory of Economic Complexity elnevezésü projektjének keretében közzétett adat (https://oec.world/en/), amely 1962 és 2014 között tartalmaz országok közötti világkereskedelmi termékáramlásokat SITC termékkódrendszerben, négy karakter mélységü bontásban. Az adat 1962 és 2000 közötti homogenizálását Feenstra és szerzőtársai [2005] végezte el, a további évekhez pedig az ENSZ Comtrade adatbázisát (https://comtrade.un.org/) vettük alapul. Az adatbázis 263 területi egység és 988 különböző termék import- és exportvolumeneit tartalmazza dollárban kifejezve. A területi egységek zöme ország, de a határok megváltozása miatt nem minden területi egység szerepel végig az adatbázisban (például Csehszlovákia). Hasonlóképpen nem minden termék szerepel az adatbázisban minden évben: összesen 506 olyan termék van, amely a teljes 1962-2014 közötti időszakban szerepel benne. A 2011 és 2014 közötti adatok esetében a hiányzó értékek száma ugrásszerủen megnő, vélhetően a világ országainak külkereskedelmére vonatkozó adatgyüjtés és feldolgozás korlátai miatt.

A technológiai közelség méréséhez a 2000-es évre vonatkozó adatbázisrészt használjuk fel, illetve kizárjuk az olyan termékáramlásokat, amelyekben Magyarország érintett. Ez utóbbira azért van szükség, mert endogenitási probléma merül fel (Boschma és szerzötársai [2013]), ha a hazai külkereskedelem szerkezetét egy olyan eszközzel vizsgáljuk, amely, legalábbis részben, a hazai export szerkezetétől függ. Így végül a technológiai közelség meghatározásához egy 229 területi egységet és 775, SITC Rev. 2. szerint kódolt terméket tartalmazó, 2000-re vonatkozó adatbázisrészt használunk. 


\section{A technológiai közelség mérése a terméktér segítségével}

Azt, hogy az egyes termékek mennyire kapcsolódnak egymáshoz, vagyis menynyire hasonló képességbázisra támaszkodnak, a termékközelség-index segítségével mérjük. Hidalgo és szerzötársai [2007] példájával a különböző országok a termeléshez szükséges képességek részben eltérö halmazával rendelkeznek, és ezeket a képességeket kombinálják termékekké. Az országok, képességek és termékek kapcsolatrendszere egy háromszintü, három különböző típusú csúcsot tartalmazó hálózatot alkot (1. ábra). A képességeket azonban közvetlenül nem tudjuk megfigyelni, adatokkal csak az ország-termék kombinációk halmazáról rendelkezünk, amelyek kétszintű hálózatot alkotnak. Ebben megfigyelve a termékek együttes előfordulását, egy termékek közötti kapcsolatrendszer rajzolódik ki, ahol a kapcsolat erőssége az együttes előfordulás gyakoriságával arányos. Azaz minél gyakrabban szerepel az országok exportportfóliójában együtt két termék, annál szorosabb a kapcsolat közöttük, illetve vélhetően annál inkább hasonló a képességbázis, amelyre a termelésükhöz szükség van. Az így kapott terméktér (product space) felépítéséből következik, hogy egy ország számára a már exportált termékektől több lépés távolságra lévő termékek elérése nem magától értetődő, a diverzifikáció során a terméktér termékei közötti mozgást korlátozza a meglévő képességbázis (Hidalgo és szerzőtársai [2007]).

\section{1. ábra}

A képességbázis implicit feltérképezése termékek együttes előfordulása alapján

Országok Képességek Termékek

Országok Termékek

Termékek
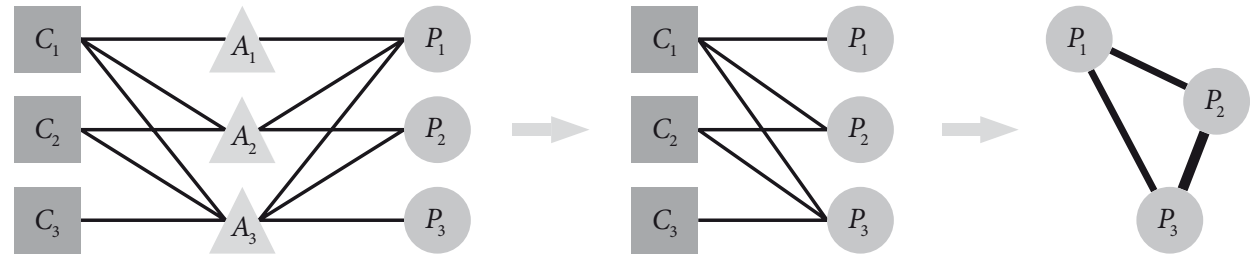

Forrás: saját szerkesztés Hidalgo-Hausmann [2009] 10 571. o. alapján.

Hidalgo és szerzötársai [2007] eljárását követve, a termékközelség-index meghatározásához elöször arra van szükség, hogy definiáljuk az egyes termékek jelenlétét az országok exportkosarában. A mérési zaj csökkentése érdekében a számítás során az exportálást egy kritikus tömeg elérése felett vesszük figyelembe, vagyis egy négy számjegyü termékkódú termék $(i=1, \ldots, M)$ akkor része egy ország $(c=1, \ldots, N)$ exportkosárának, ha abban a kérdéses ország feltárt komparatív elönnyel $\left(R C A_{c, i}\right)$ rendelkezik. Ez azt fejezi ki, hogy hogyan viszonyul egy termék exportvolumenének $\left(X_{c, i}\right)$ részesedése az országos exportból $\left(X_{c}\right)$ a termékek exportvolumenének $\left(X_{i}\right)$ részesedéséhez a világexportból $(X)$ :

$R C A_{c, i}=\frac{X_{c, i} / X_{c}}{X_{i} / X}$ 
A mutató értékei a $[0, \infty)$ tartományon szóródnak, egy ország pedig akkor rendelkezik komparatív előnnyel egy termék exportjában, ha a feltárt komparatív előny nagysága meghaladja az 1-et.

A következő lépés annak a valószínüségnek a meghatározása, hogy egy ország komparatív előnnyel rendelkezik-e egy termék exportjában. Ehhez az egy tetszőleges négy számjegyü termékkódú termékben $(i=1, \ldots, M)$ komparatív előnnyel rendelkező országok számát $\left(n_{i} \leq N\right)$ elosztjuk a mintában szereplő országok számával:

$p_{i}=\frac{n_{i}}{N}$

A kapott termékszintű mutató értékkészlete 0 és 1 közötti, a magasabb érték azt jelenti, hogy egy termékben az országok nagyobb hányada alakít ki komparatív előnyt. Vélhetően az olyan termékek termelése, amelyekben számos ország alakít ki komparatív előnyt, olyan képességbázis meglétét feltételezi, amely sok országban megtalálható.

Ezt követően annak az együttes valószínüségét határozzuk meg, hogy egy országnak egyszerre van komparatív előnye két termék $(i=1, \ldots, M ; j=1, \ldots, M ; i \neq j)$ exportjában. Ehhez elosztjuk azoknak az országoknak a számát $\left(n_{i j}\right)$, amelyek mindkét termékben komparatív előnnyel rendelkeznek, a mintában szereplő országok számával $(N=229)$ :

$p_{i j}=\frac{n_{i j}}{N}$.

A kapott termékkombináció-szintű mutató ismét 0 és 1 között szóródik, magasabb értéke esetén az országok nagyobb hányada alakít ki komparatív előnyt a kérdéses termékkombinációban. Ez a részszámítás már valamelyest utal az egyes termékek mögötti képességbázis átfedésére, azonban értéke olyan termékpárok esetében lesz magas, amelyekhez kevésbé speciális képességbázisra van szükség. Pedig olyan termékek között is erős lehet a technológiai közelség, amelyeket az országok szük köre képes csak elöállítani a speciális tudásigény miatt.

Éppen ezért negyedik lépésként azt a feltételes valószínűséget kell meghatároznunk, amely azt mutatja, hogy egy országnak komparatív előnye van egy termék $(i=1, \ldots, M)$ exportjában, ha komparatív előnnyel rendelkezik egy másik termék $(j=1, \ldots, M ; i \neq j)$ exportjában. Ehhez az előbbi $p_{i j}$ együttes valószínüséget kell elosztanunk a korábban kapott $p_{j}$ valószínüséggel:

$P\left(R C A_{i} \mid R C A_{j}\right)=\frac{p_{i j}}{p_{j}}$.

Ezzel a módszerrel termékpáronként két feltételes valószínűséget kapunk: a $P\left(R C A_{i} \mid R C A_{j}\right)$-t és a $P\left(R C A_{j} \mid R C A_{j}\right)$-t, amelyek 0 és 1 közötti értéket vehetnek fel.

Végül a közelségi indexet $\left(\varphi_{i j}\right)$ úgy definiáljuk, mint az előbb kapott két feltételes valószínűségének minimumát:

$\varphi_{i j}=\min \left\{P\left(R C A_{i} \mid R C A_{j}\right), P\left(R C A_{j} \mid R C A_{i}\right)\right\}$. 
A minimum használatának két előnye van. Egyrészt abban az esetben, ha egy terméket egyetlen ország exportál, akkor 1 lesz annak a valószínüsége, hogy az ország exportportfóliójának többi elemét ezzel a termékkel együtt exportálja. Ennek a fordítottja viszont nem igaz, ezért a minimum használatával ezt a torzítási lehetőséget korlátozzuk. Másrészt a technológiai közelség egyfajta kölcsönös kapcsolatot fejez ki két termék között, vagyis jó, ha egy termékpárhoz egyetlen érték tartozik (Hidalgo és szerzőtársai [2007]). Az index ennek megfelelően egy termékpárra vonatkozó mutató, amely 0 és 1 közötti értéket vehet fel. A mutató magasabb értéke arra utal, hogy két termék előállításához inkább hasonló, termelésben megtestesülő tudásra van szükség.

A vizsgált 775 termék között ilyen módon meghatározott páronkénti technológiai közelségek alkalmasak arra, hogy a hálózatelemzés eszközeivel vizsgáljuk őket. A kapott hálózat összesen 299925 irányítatlan élt tartalmaz. E terméktér élsúlyainak sürüségfüggvénye bal oldali eltolódást mutat, vagyis sok olyan termékpár van, amelyek között gyenge a technológiai közelség, és kevés olyan, amelyek között erös. A termékközelség-indexek körülbelül 30 százaléka 0,1-nél, körülbelül 65 százaléka 0,2-nél, körülbelül 99 százaléka pedig 0,55-nál alacsonyabb értéket vesz fel. Mivel a terméktér szerkezete időben lassan változik (Elekes [2017], a 2000 és 2011 közötti időszakban stabilnak tekinthetjük, így a további elemzés során a 2000es termékteret használjuk fel (2. ábra).

2. ábra

A teljes 2000-es terméktér és a magyarországi alháló

A) A 2000-es terméktér

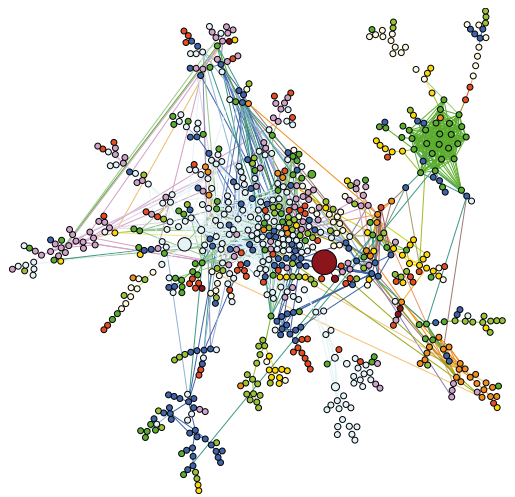

B) A 2000-es terméktér Magyarországon

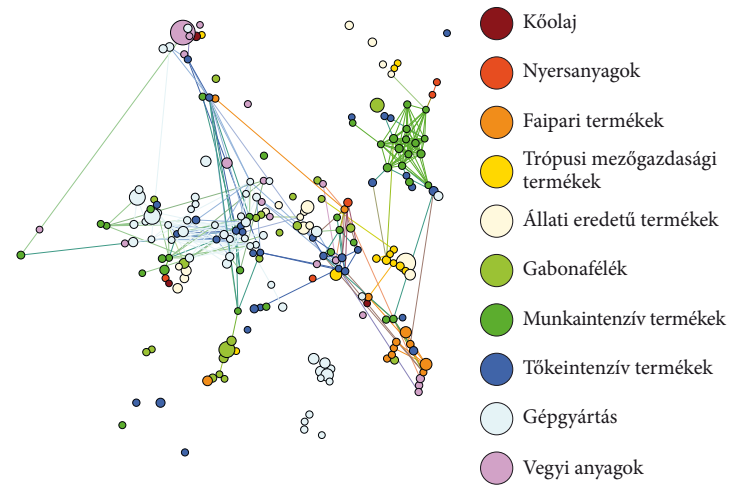

Megjegyzés: a csúcsok mérete a teljes terméktér esetében a világkereskedelmi export volumenével, a magyarországi alháló esetében a feltárt komparatív előnnyel arányos. Az átlátható vizualizáció érdekében csak az az 1547 él került ábrázolásra, amelyek részei a terméktér maximális feszítőájának, vagy az élek legerősebb 0,54 százalékához tartoznak. A Gephi szoftver ForceAtlas2 elrendezését alkalmaztuk (Jacomy és szerzötársai [2014]). A magyarországi alhálóban csak azok a termékek szerepelnek, amelyekben az ország komparatív előnnyel rendelkezik. A csúcsok koordinátái a két hálóban megegyeznek. A termékcsoportok színkódolása a Leamer-féle osztályozáson alapul (Leamer [1984]).

Forrás: saját szerkesztés Hidalgo és szerzőtársai [2007] 483. o. alapján. 


\section{Változók}

A regionális diverzifikációs mintázatok feltárásához arra van szükség, hogy összekössük az egyes termékek megjelenését a térségben már jelen lévő termékek portfóliójával. Erre a célra a sürüség mutatóját használjuk, amely azt mutatja meg, hogy egy tetszőleges négy számjegyü termékkódú exporttermék $(i=1, \ldots, M)$ körül egy kiválasztott régióban $(r=1, \ldots, R)$, egy kiválasztott évben $(t=1, \ldots, T)$ milyen mértékben vannak jelen kapcsolódó exporttermékek $(j=1, \ldots, M ; i \neq j)$ (Hausmann-Klinger [2007], Hidalgo és szerzőtársai [2007], Boschma és szerzőtársai [2013]):

$\operatorname{XDENSITY}_{i, r, t}=\frac{\sum_{j} \varphi_{i j} X R C A_{j, r, t}^{i n d}}{\sum_{j} \varphi_{i j}}$.

A sürüség lényegében egy súlyozott átlag, ahol az egyes exporttermékeket akkor vesszük figyelembe egy térségben, ha a feltárt komparatív előny $\left(X R C A_{j, r, t}\right)$ nagyobb, mint 1 (ekkor $X R C A_{j, r, t}^{\text {ind }}=1$, különben 0 ), a súlyok pedig a kiválasztott termékhez kapcsolódó termékek közelségindexei $\left(\varphi_{i j}\right)$. A kapott termék-régió kombinációkra vonatkozó mutató értékkészlete a $[0,1]$ intervallum, ahol a magasabb érték arra utal, hogy egy régióban több kapcsolódó exporttermék van jelen.

Mivel az exporttermékek előállításához szükséges képességek egy része az importon keresztül a régión kívülről is származhat, ezért az empirikus elemzés során arra is kíváncsiak vagyunk, hogy egy termék körüli kapcsolódó importtermékek sürüsége befolyásolja-e az abban kialakított komparatív elönyt. Ehhez a fent leírtakhoz hasonlóan minden évre $(t=1, \ldots, T)$ és minden vizsgált régióban $(r=1, \ldots, R)$ létrehozunk egy regionalizált termékteret, amelyben egy importterméket $(i=1, \ldots, M)$ akkor tekintünk jelen lévőnek, ha abban a térségnek komparatív hátránya van, vagyis a részesedése a regionális importból meghaladja a termék részesedését az országos importból (ekkor IMPRCA ind $=1$, különben 0 ). Egy termék importsürüsége $\left(I M P D E N S I T Y_{i, r, t}\right)$ ebben az esetben is a más termékekhez $(j=1, \ldots, M ; i \neq j)$ viszonyított technológiai közelségekkel $\left(\varphi_{i j}\right)$ való súlyozásból adódik:

$\operatorname{IMPDENSITY}_{i, r, t}=\frac{\sum_{j} \varphi_{i j} \operatorname{IMPRCA}_{j, r, t}^{\text {ind }}}{\sum_{j} \varphi_{i j}}$.

Ennek a változónak az 1-hez közeli értéke arról árulkodik, hogy egy termék körül sok kapcsolódó terméket importálnak a vizsgált régióban, vagyis a szükséges képességek jelentős része a régión kívül érhető el.

A magyar feldolgozóipari exportra jellemző magas importhányad miatt egy termék export- és importsürűsége erősen (0,63 szinten) korrelál. Ezt az erős korrelációt a kapcsolódó kutatásokhoz hasonlóan úgy kezeljük (Boschma-Capone [2016]), hogy az import sürüségét (IMPDENSITY $\left.{ }_{i, r, t}\right)$ egy segédregresszió keretében az exportsürüséggel $\left(X D E N S I T Y_{i, r, t}\right)$ magyarázzuk, és a maradéktagot $\left(\varepsilon_{i, r, t}\right)$ használjuk importsürüségként (IMPDENSITY $\left.Y_{i, r, t}^{R E S}\right)$ a fö regressziós elemzésben:

$\operatorname{IMPDENSITY}_{i, r, t}=\mathrm{XDENSITY}_{i, r, t}+\varepsilon_{i, r, t}$. 
$\operatorname{IMPDENSITY} Y_{i, r, t}^{R E S}=\varepsilon_{i, r, t}$.

A kapott maradékok ilyen módon az importsűrüség exporttól megtisztított értékét képviselik. Azt mutatják, hogy mennyivel sürübb az importterméktér egy termék körül, mint amit az exportterméktér alapján várnánk. Magas értékek esetén több olyan termék és mögöttes képesség válik hozzáférhetővé a régió számára, amelyek távolabb állnak a régió meglévő képességbázisától.

Az export- és importtermék-sürüséget külföldi-hazai bontásban is meghatároztuk. Ez úgy történt, hogy a fenti számításokat megismételtük csak a hazai vállalatok, illetve csak a külföldi vállalatok export- és importtermékeit figyelembe véve (az alapváltozók leíró statisztikáit lásd 1. táblázat). A hazai-külföldi bontás nélküli terméksürüség azt feltételezi, hogy egy-egy térség vállalatai tulajdonostól függetlenül ugyanazt a helyi képességbázist használják ugyanolyan módon. Ezzel szemben a tulajdonosi dimenziót figyelembe vevő sürüségmutatók azt feltételezik, hogy a két vállalatcsoport részben a rá jellemző helyi képességbázissal áll kapcsolatban.

\section{1. táblázat}

A terméksürüségre vonatkozó statisztikák

\begin{tabular}{lccccc}
\hline Változó & Átlag & Szórás & Minimum & Maximum & $N$ \\
\hline XDENSITY $_{i, r, t}$ & 0,047 & 0,032 & 0,000 & 0,405 & 232200 \\
XDENSITY Y,r,t $^{D}$ & 0,039 & 0,032 & 0,000 & 1,000 & 232200 \\
XDENSITY $_{i, r, t}^{F}$ & 0,034 & 0,027 & 0,000 & 0,405 & 232200 \\
IMPDENSITY $_{i, r, t}$ & 0,089 & 0,044 & 0,000 & 0,483 & 232200 \\
IMPDENSITY $_{i, r, t}^{D}$ & 0,067 & 0,045 & 0,000 & 1,000 & 232200 \\
IMPDENSITY Y $_{i, r, t}^{F}$ & 0,072 & 0,040 & 0,000 & 0,405 & 232200 \\
\hline
\end{tabular}

Forrás: saját szerkesztés.

\section{Alkalmazott módszer}

A regionális exportportfólió lassan változik, ezért a vizsgált 12 évet periódusokra bontjuk, a regressziós elemzéshez összesen négy hároméves periódust használunk $(t=1, \ldots, 4)$. A modell kétértékủ célváltozója az exportbeli komparatív elöny megléte $\left(X R C A_{i, r, t+1}^{\text {ind }}=1\right.$, ha $\left.X R C A_{i, r, t+1}>1\right)$ a következő periódusban. Ez a lépés az egyes régiók húzóágazataira helyezi a hangsúlyt az elemzésben, és elterjedt eljárás a diverzifikáció (Hausmann-Klinger [2007]), illetve a regionális klaszterek vizsgálatában (Vas és szerzőtársai [2015]). A komparatív előny 1 körüli ingadozásának mérséklése érdekében a komparatív előnyök perióduson belüli átlagát használjuk. A többi vizsgált változó a periódus elejére vonatkozik. Hausmann-Klinger [2007] modelljét alkalmazzuk, amely szerint a következő periódusban megfigyelt termék-régió kombinációra vonatkozó komparatív előny megléte $\left(X R C A_{i, r, t+1}^{\text {ind }}\right)$ a vizsgált periódusban megfigyelt komparatív előny megléte $\left(X R C A_{i, r, t}^{\text {ind }}\right)$, a kapcsolódó termékek regionális 
sürüségének vektora $\left(D E N S I T Y_{i, r, t}\right)$, a kontrollváltozók (a régió népsürüségének logaritmusa: $\log P O P D E N S_{r, t}$, fix hatások: $\delta_{g}$ és $\left.\tau_{t}\right)$ és a hibatag $\left(\varepsilon_{i, r}\right)$ függvénye:

$$
X R C A_{i, r, t+1}^{\text {ind }}=\alpha X R C A_{i, r, t}^{\text {ind }}+\beta D E N S I T Y_{i, r, t}+\gamma \log \operatorname{POPDENS}_{r, t}+\delta_{g}+\tau_{t}+\varepsilon_{i, r, t} .
$$

A következő periódusbeli komparatív előny kétféleképpen jöhet létre. Egyrészt azért, mert egy új termék jelenik meg a regionális exportportfólióban, másrészt azért, mert fennmarad egy már meglévő termékbeli komparatív előny. A kettő elkülönítéséhez Hausmann-Klinger [2007] eljárását követve az exportbeli komparatív előny megléte $\left(X R C A_{i, r, t}^{\text {ind }}\right)$ és a kapcsólódó terméksürüségek $\left(D E N S I T Y_{i, r}\right)$ közötti interakciókat építünk a modellbe:

$$
\begin{aligned}
& X R C A_{i, r, t+1}^{\text {ind }}=\alpha X R C A_{i, r, t}^{\text {ind }}+\beta_{1} X R C A_{i, r, t}^{\text {ind }} \times \operatorname{DENSITY~}_{i, r, t}+\beta_{2}\left(1-X R C A_{i, r, t}^{\text {ind }}\right) \times \\
& \times \text { DENSITY }_{i, r, t}+\gamma \log \text { POPDENS }_{r, t}+\delta_{g}+\tau_{t}+\varepsilon_{i, r, t} .
\end{aligned}
$$

Ez a modellváltozat minden sủrüségmutatóra két együtthatót becsül $\left(\beta_{1}\right.$ és $\left.\beta_{2}\right)$. Egyet a már a portfólióban szereplö, meglévő termék körüli sürüség hatására $\left(\beta_{1}\right)$, egyet pedig az újonnan megjelenő termék körüli sürüség hatására $\left(\beta_{2}\right)$.

A modellek együtthatóinak becsléséhez OLS regressziót használunk. A lineáris valószínűségi modell - különösen a nagyon alacsony valószínűségek esetén - nem feltétlenül ad pontos becslést, ezért a modellek robusztusságát logit és probit modellel is ellenőriztük. Fontos azonban megjegyezni, hogy ezek alkalmazása sem problémamentes, mivel nagyszámú bináris magyarázó változó esetén a logit és probit modellek torzított és inkonzisztens becslést adhatnak (Greene [2008]). A robusztusság vizsgálatához futtatott logit és probit modellek nem mondanak ellent a lineáris valószínűségi modellek eredményeiböl levont következtetéseknek.

Az egyes modellekben kontrollváltozóként szerepel a komparatív előny megléte $\left(X R C A_{i, r, t}^{i n d}\right)$ a vizsgált periódusban, mivel annak a valószínüségét, hogy egy termékben komparatív előny lesz a következő periódusban, értelemszerűen befolyásolja, hogy a termék korábban jelen volt-e a régió portfóliójában. Emellett termékfixhatások $\left(\delta_{g^{\prime}}\right.$ ahol $g$ a SITC 2 számjegyü termékkódot jelöli) és periódus-fixhatások $\left(\tau_{t}\right)$ szerepelnek a modellekben, valamint az egyes régiók méretére, városiasságára vonatkozó kontrollváltozó. Az exporttermék-szerkezet időbeli változása függ ettől, mivel a térbeli koncentrációból eredően szélesebb a helyben meglévő képességbázis (Balland-Rigby [2017]), amelyet így nagyobb eséllyel lehet új termékekké kombinálni. Ezenfelül a városiasabb térségekben munkaerő szempontjából nagyobb eséllyel sürüsödnek a kiegészítő viszonyban álló képességek (Neffke [2019]). Ezeknek a hatásoknak a megjelenítésére a régió népsürűségét használjuk, a hazai térszerkezet Budapest által dominált népsürüség-eloszlása miatt tízes alapú logaritmus formájában $\left(\log P O P D E N S_{r, t}\right)$.

A modellekbe kerülő változók közötti korrelációs együtthatók döntően 0,6 alatti értéket vesznek fel. Ez alól az import- és az exportsürüségek, illetve ezeknek a tulajdonos szerinti bontásával kapott változók jelentenek kivételt, amelyeket azonban nem használunk egyazon modellen belül, hanem az importsürüségek helyett a fent bevezetett maradéktagokat használjuk. Erős korrelációt mutat a külföldi vállalatok 
komparatív előnyének megléte $\left(X R C A_{i, r, t}^{F, \text { ind }}\right)$ a tulajdonos szerinti bontás nélküli komparatív elöny meglétével $\left(X R C A_{i, r, t}^{\text {ind }}\right)$. Ezek a változók azoban nem kerülnek egyazon modellbe. Összességében a modellekben szereplő változók VIF- (variance inflation factors) értékei 2,5 alattiak, így nem számítunk multikollinearitásra közöttük.

\section{Eredmények}

A hazai térségekben megfigyelhető regionális diverzifikációt három lépésben tárjuk fel. Elöször egy átfogó képet nyújtunk az új termékek megjelenésének empirikus valószínűsége és a terméksűrűség kapcsolatáról. Ezt az összefüggést azután a korábban specifikált regressziós modellek segítségével formalizáltan is teszteljük, előbb a terméksürüség külföldi-hazai bontása nélkül, majd annak figyelembevételével.

\section{Exportdiverzifikáció a hazai térségekben}

Az exporttermék-sürüségek eloszlásából az látszik, hogy átlagosan valamivel nagyobb a kapcsolódó exporttermékek regionális jelenléte azok körül a termékek körül, amelyekben a vizsgált régiók egy következő periódusban komparatív előnyt alakítanak ki (3. ábra). Az eloszlásokat kétoldali Kolmogorov-Smirnov-teszt (KS-teszt) segítségével összehasonlítva szignifikánsan különbözik a terméksűrüségek eloszlása. Az egyoldali tesztek alapján az új termékek körüli terméksürüség-eloszlás 1 százalékos szignifikanciaszinten sztochasztikusan dominálja azokét a termékekét, amelyekben nem alakult ki komparatív előny. Ezek arra utalnak, hogy az új exporttermékek megjelenését a térségek meglévő exportszerkezete befolyásolja, és az új termék által feltételezett képességbázis minél szélesebb regionális jelenléte segíti.

A diverzifikációra vonatkozó eredmények értékelése szempontjából lényeges kérdés, hogy vajon az exporttermék-sűrüség gazdasági értelemben szignifikáns kapcsolatban áll-e az új termékek megjelenésével az exportportfólióban. Éppen ezért meghatározzuk annak az empirikus valószínűségét, hogy egy új termék megjelenik a vizsgált régiók exportkosarában. Ehhez elöször egy-egy perióduspárra megszámoljuk, hogy hány olyan termék van, amely egy-egy régió exportportfóliójában egy periódusban nem mutat koncentrációt $\left(X R C A_{i, r, t} \leq 1\right)$, a következöben viszont igen $\left(X R C A_{i, r, t+1}>1\right)$. Ez az érték megadja azoknak az eseteknek a számát, amikor egy régió két periódus között új termékben alakított ki komparatív előnyt. Ezt azután elosztjuk azoknak az eseteknek a számával, a mikor egy-egy régió egy periódusban nem rendelkezett komparatív előnnyel. Ez az érték fejezi ki a potenciális diverzifikációs lehetőségek számát. A kettő hányadosa egy empirikus valószínűség, amely azt mutatja meg, hogy a lehetséges diverzifikációk hány százaléka valósult meg. A valószínűségeket három perióduspár összevonásával határozzuk meg.

Azt a megfigyelést tehetjük, hogy a terméksürüség növekedésével nő annak az empirikus valószínűsége, hogy egy új termék megjelenik a regionális exportportfólióban (4.a ábra). Ez a valószínüség 1 és 10 százalék között mozog attól függően, 
3. ábra

Új termékek és komparatív előnnyel nem rendelkező termékek sűrüségfüggvényei 2000 és 2011 között hároméves intervallumokkal

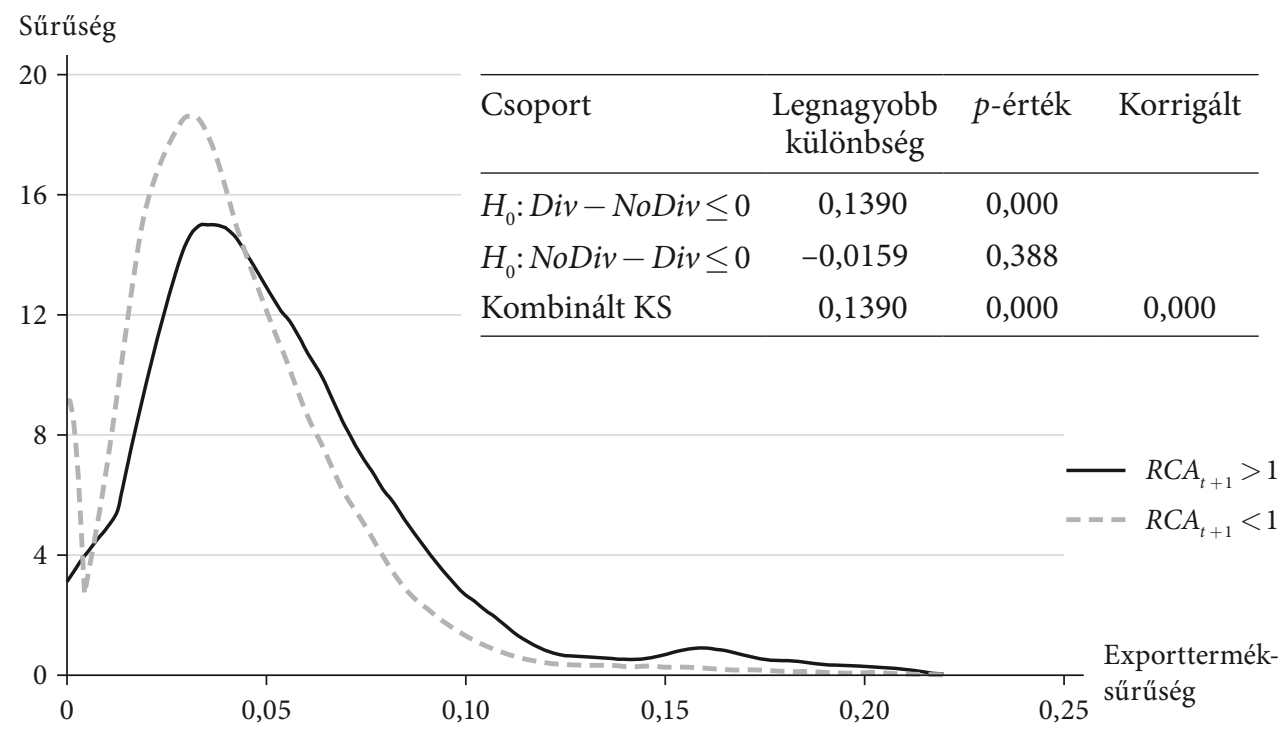

Megjegyzés: a KS-tesztekben Div jelöli egy korábban hiányzó termék megjelenését, a NoDiv pedig azokat a termékeket jelöli, amelyekben nem volt és a következő periódusra nem is alakult ki komparatív előny.

Forrás: saját szerkesztés.

hogy mennyire sok kapcsolódó termék van jelen a térségekben. Az összefüggés külföldi-hazai bontásban is megfigyelhetö, a hazai vállalatok termékei esetében 8 százalék (4.b ábra), a külföldi vállalatok esetében 5 százalék körüli maximumot ér el (4.c ábra). Megjegyzendő, hogy a hazai vállalatok száma meghaladja a külföldiekét, ami tükröződik a befogadó gazdaságra jellemző, átlagosan magasabb exporttermék-sürűségben. Ennek ellenére mindkét esetben gazdasági értelemben is jelentősnek tűnik a sürüség kapcsolata a diverzifikációval. Azt is fontos megjegyezni, hogy amennyiben a külföldi tulajdonú vállalatok magasabb hozzáadott értékü, komplexebb termékek termelését végzik a régiókban, akkor kisebb számuk és a diverzifikáció valamivel kisebb valószínüsége ellenére a helyi gazdaságra gyakorolt hatásuk jelentős lehet. 
4. ábra

Új termék megjelenésének valószínűsége 2000 és 2011 között hároméves intervallumokkal

a) Teljes termékminta

Valószínűség

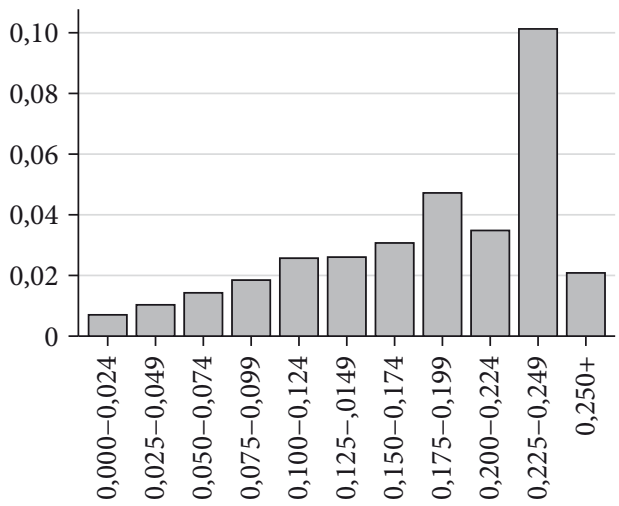

Exporttermék-sürűség b) A hazai vállalatok termékei

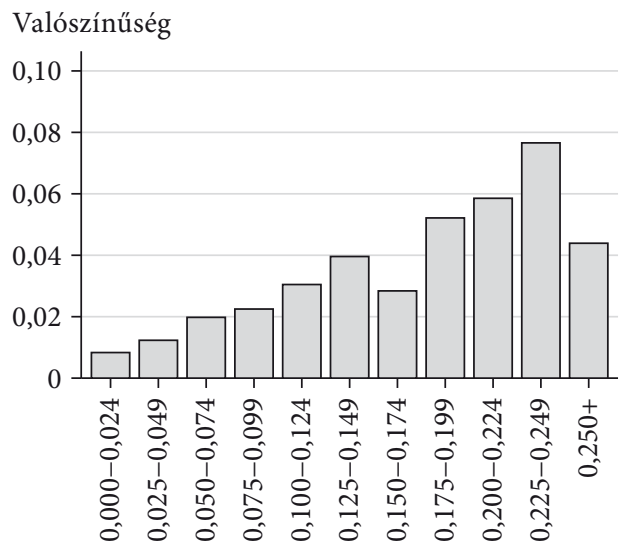

Exporttermék-sürüség

c) A külföldi tulajdonú vállalatok termékei

Valószínűség

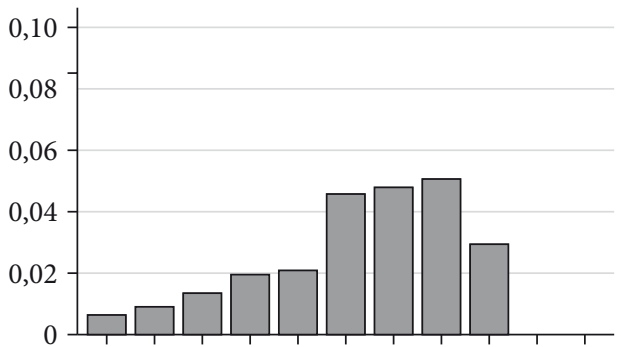

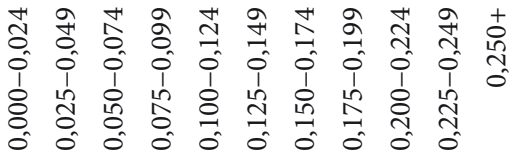

Exporttermék-sürüség

Megjegyzés: az ábrák vízszintes tengelye a terméksűrüség-eloszlás 0,025 széles intervallumait mutatja a releváns tartományon.

Forrás: saját szerkesztés.

\section{A terméksürüség szerepe a hazai térségek exportdiverzifikációjában}

A regressziós eredmények közül elöször az exporttermékek aggregált terméksürüségének jelentőségére helyezzük a hangsúlyt (2. táblázat). A kontrollváltozók közül a komparatív elöny egy exporttermékben (XRCA $A_{i, r, t}^{\text {ind }}, X R C A_{i, r, t}^{D, \text { ind }}$ és $\left.X R C A_{i, r, t}^{F, \text { ind }}\right)$ minden modellben egyöntetüen erös pozitív irányú kapcsolatban van a jövőbeli komparatív elönnyel a vizsgált exporttermékekben. A népsürüség $\left(\log P O P D E N S_{r, t}\right)$ kapcsolata az exportbeli 
komparatív előny kialakításával egyáltalán nem szignifikáns [(1) és (2) modell]. Tulajdonos szerinti bontásban világossá válik, hogy ez elsősorban a külföldi tulajdonú vállalatok termékei miatt van így, amelyek jövőbeni jelenlétét nem befolyásolja a régió mérete [(5) és (6) modell]. Ezzel szemben a hazai vállalatok termékei esetében statisztikai értelemben erősen szignifikáns kapcsolat mutatkozik [(3) és (4) modell].

\section{2. táblázat}

Az aggregált terméksürüség és az exporttermékekben jelentkező komparatív előny kapcsolata

\begin{tabular}{|c|c|c|}
\hline & (1) modell & (2) modell \\
\hline & összes $\left(X R C A_{i, r, t+1}^{\text {ind }}\right)$ & összes $\left(X R C A_{i, r, t+1}^{\text {ind }}\right)$ \\
\hline $\log P O P D E N S_{r, t}$ & $\begin{array}{c}-0,001 \\
(-0,19)\end{array}$ & $\begin{array}{c}-0,001 \\
(-0,31)\end{array}$ \\
\hline$X R C A_{i, r, t}^{\text {ind }}$ & $\begin{array}{c}0,659^{* * *} \\
(65,88)\end{array}$ & $\begin{array}{c}0,632^{* * *} \\
(39,63)\end{array}$ \\
\hline$X_{D E N S I T Y} Y_{i, r, t}$ & $\begin{array}{l}0,037^{* * *} \\
(9,62)\end{array}$ & \\
\hline$I M P D E N S I T Y_{i, r, t}^{R E S}$ & $\begin{array}{l}0,013^{\star *} \\
(2,73)\end{array}$ & \\
\hline$X R C A_{i, r, t}^{\text {ind }} \times X D E N S I T Y_{i, r, t}$ & & $\begin{array}{l}0,049^{\star *} \\
(2,90)\end{array}$ \\
\hline$\left(1-X R C A_{i, r, t}^{i n d}\right) \times X \operatorname{DENSITY} Y_{i, r, t}$ & & $\begin{array}{c}0,032^{* * *} \\
(10,04)\end{array}$ \\
\hline$X R C A_{i, r, t}^{\text {ind }} \times I M P D E N S I T Y_{i, r, t}^{R E S}$ & & $\begin{array}{r}0,000 \\
(0,04)\end{array}$ \\
\hline$\left(1-X R C A_{i, r, t}^{\text {ind }}\right) \times I M P D E N S I T Y_{i, r, t}^{R E S}$ & & $\begin{array}{l}0,014^{* * *} \\
(3,64)\end{array}$ \\
\hline Periódus-fixhatás & igen & igen \\
\hline Termék-fixhatás (SITC2) & igen & igen \\
\hline Megfigyelések száma & 174150 & 174150 \\
\hline Kiigazított $R^{2}$ & 0,455 & 0,455 \\
\hline
\end{tabular}

\begin{tabular}{|c|c|c|}
\hline & (3) modell & (4) modell \\
\hline & hazai $\left(X R C A_{i, r, t+1}^{D, \text { ind }}\right)$ & hazai $\left(X R C A_{i, r, t+1}^{D, \text { ind }}\right)$ \\
\hline $\log P O P D E N S_{r, t}$ & $\begin{array}{l}0,014^{\star *} \\
(3,17)\end{array}$ & $\begin{array}{l}0,014^{* *} \\
(3,07)\end{array}$ \\
\hline$X R C A_{i, r, t}^{D, \text { ind }}$ & $\begin{array}{c}0,553^{* * *} \\
(45,14)\end{array}$ & $\begin{array}{c}0,528^{* * *} \\
(29,15)\end{array}$ \\
\hline XDENSITY $_{i, r, t}$ & $\begin{array}{l}0,042^{* * *} \\
(9,13)\end{array}$ & \\
\hline$I M P D E N S I T Y_{i, r, t}^{R E S}$ & $\begin{array}{c}-0,004 \\
(-0,98)\end{array}$ & \\
\hline
\end{tabular}




\section{A 2. táblázat folytatása}

\begin{tabular}{|c|c|c|}
\hline & (3) modell & (4) modell \\
\hline & hazai $\left(X R C A_{i, r, t+1}^{D \text {, ind }}\right)$ & hazai $\left(X R C A_{i, r, t+1}^{D, \text { ind }}\right)$ \\
\hline$X R C A_{i, r, t}^{D, \text { ind }} \times X D E N S I T Y_{i, r, t}$ & & $\begin{array}{l}0,048^{\star *} \\
(2,77)\end{array}$ \\
\hline$\left(1-X R C A_{i, r, t}^{D, \text { ind }}\right) \times X \operatorname{XENSITY} Y_{i, r, t}$ & & $\begin{array}{l}0,035^{* * *} \\
(8,47)\end{array}$ \\
\hline$X R C A_{i, r, t}^{D, \text { ind }} \times I M P D E N S I T Y_{i, r, t}^{R E S}$ & & $\begin{array}{c}-0,028^{\star} \\
(-2,16)\end{array}$ \\
\hline$\left(1-X R C A_{i, r, t}^{D, \text { ind }}\right) \times I M P D E N S I T Y_{i, r, t}^{R E S}$ & & $\begin{array}{c}0,004 \\
(1,19)\end{array}$ \\
\hline Periódus-fixhatás & igen & igen \\
\hline Termék-fixhatás (SITC2) & igen & igen \\
\hline Megfigyelések száma & 174150 & 174150 \\
\hline Kiigazított $R^{2}$ & 0,333 & 0,334 \\
\hline
\end{tabular}

(5) modell (6) modell

külföldi $\left(X R C A_{i, r, t+1}^{F, \text { ind }}\right) \quad$ külföldi $\left(X R C A_{i, r, t+1}^{F, \text { ind }}\right)$

$\log$ POPDENS $_{r, t}$

$\begin{array}{cc}0,005 & 0,004 \\ (1,17) & (1,20)\end{array}$

$X R C A_{i, r, t}^{F, \text { ind }}$

$0,647^{* * *}$

$(1,20)$

0,647
$(55,47)$

$0,625^{\star * *}$

XDENSITY $_{i, r, t}$

$0,035^{* * *}$

$(28,92)$

$(7,23)$

IMPDENSITY $Y_{i, r, t}^{R E S}$

$(3,57)$

$\mathrm{XRCA}_{i, r, t}^{F, \text { ind }} \times \mathrm{XDENSITY}_{i, r, t}$

$\left(1-X R C A_{i, r, t}^{F, \text { ind }}\right) \times \operatorname{XDENSITY}_{i, r, t}$

$X R C A_{i, r, t}^{F, \text { ind }} \times I M P D E N S I T Y_{i, r, t}^{R E S}$

$\left(1-X R C A_{i, r, t}^{F, \text { ind }}\right) \times I M P D E N S I T Y_{i, r, t}^{R E S}$

Periódus-fixhatás

Termék-fixhatás (SITC2)

igen

igen

igen

igen

Megfigyelések száma

174150

174150

Kiigazított $R^{2}$

0,437

0,437

Megjegyzés: standardizált béta együtthatók; $t$-értékek zárójelben.

${ }^{\star} p<0,05,{ }^{* *} p<0,01,{ }^{* *} p<0,001$.

Forrás: saját szerkesztés. 
Megfigyelhetö, hogy a kapcsolódó exporttermékek sürüsége $\left(X_{D E N S I T Y_{i, r, t}}\right)$ egy termék körül pozitívan hat annak későbbi jelenlétére, és ugyanez mondható el az importtermékek sűrüségéről is (IMPDENSITY $Y_{i, r, t}^{R E S}$ ) [(1) modell]. Utóbbi arra utal, hogy az exporthoz kapcsolódó import által becsatornázott, régión kívüli képességbázis hat az exporttermékek térségi jelenlétére. A meglévő, illetve új exporttermékeket elkülönítve az is látszik, hogy az exportsűrüség egyaránt segíti a már jelen lévő termékek megmaradását $\left(X R C A_{i, r, t}^{\text {ind }} \times X D E N S I T Y_{i, r, t}\right)$ és az új termékek megjelenését $\left[\left(1-X R C A_{i, r, t}^{\text {ind }}\right) \times X D E N S I T Y_{i, r, t}\right]$ egy-egy térségben [(2) modell]. Vagyis a szélesebb kapcsolódó képességbázis megléte valószínübbé teszi az egy-egy exporttermékben kialakított komparatív előny fenntartását, ezáltal pedig stabilizálja a regionális export szerkezetét. Ugyanakkor a kapcsolódó termékekkel közös képességbázis érdemben befolyásolja az új termékek megjelenését is. Érdekes eredmény, hogy az exporthoz kapcsolódó import kifejezetten az új exporttermékben kialakuló komparatív előnyt segíti $\left[\left(1-X R C A_{i, r, t}^{\text {ind }}\right) \times I M P D E N S I T Y_{i, r, t}^{R E S}\right]$. Ez azt a nagyon fontos összefüggést jelenti, hogy a regionális exportkosár diverzifikációjához hozzájárulnak azok a képességek is, amelyekhez a térség az import csatornáján keresztül a régión kívül fér hozzá.

Ha az elemzést a hazai vállalatok által előállított exporttermékekre szükítjük, akkor az exporttermék-sürüség $\left(X_{D E N S I T Y}{ }_{i, r, t}\right)$ hatása megmarad, míg az importtermék-sürüség (IMPDENSITY $\left.Y_{i, r, t}^{R E S}\right)$ hatása eltünik [(3) modell]. A kapcsolódó exporttermékek jelenléte a hazai vállalatok által termelt exporttermékek fennmaradását $\left(X R C A_{i, r, t}^{D, \text { ind }} \times X D E N S I T Y_{i, r, t}\right)$ és az új termékek megjelenését $\left[\left(1-X R C A_{i, r, t}^{D, \text { ind }}\right) \times X D E N S I T Y_{i, r, t}\right]$ egyaránt segíti [(4) modell]. A külföldi tulajdonú vállalatok által előállított és exportált termékek esetében az exportterméksürüség $\left(X D E N S I T Y_{i, r, t}\right)$ ismét pozitív kapcsolatot mutat a komparatív előny jövőbeli meglétével [(5) modell]. Érdekes eredmény, hogy a külföldi tulajdonú vállalatok által exportált termékek szerkezetére az importsürüség (IMPDENSITY $\left.Y_{i, r, t}^{R E S}\right)$ is pozitív hatással van. Ez arra utal, hogy a regionális diverzifikáció szempontjából a külföldi tulajdonú vállalatok az import által becsatornázott régión kívüli képességeket eredményesen kombinálják a helyben meglévő képességbázissal. Végül megfigyelhetö, hogy az export- $\left.\left[\left(1-X R C A_{i, r, t}^{F, \text { ind }}\right) \times X D E N S I T Y_{i, r, t}\right)\right]$ és importtermék-sürüség $\left.\left[\left(1-X R C A_{i, r, t}^{F, \text { ind }}\right) \times I M P D E N S I T Y_{i, r, t}^{R E S}\right)\right]$ a külföldi tulajdonú vállalatok exporttermékei esetében kifejezetten az új termékek megjelenését segíti elö a térségekben [(6) modell].

\section{Regionális diverzifikáció a terméksürüség külföldi-hazai bontása alapján}

A regionális diverzifikációról alkotott képet azzal árnyaljuk tovább, hogy felbontjuk a terméksűrűséget a hazai, illetve külföldi tulajdonú vállalatok által exportált és importált termékekben megfigyelhető sürüségre (3. táblázat). Megfigyelhető, hogy mind a hazai $\left(X D E N S I T Y_{i, r, t}^{D}\right)$, mind a külföldi tulajdonú vállalatok által exportált termékek sürüsége $\left(X D E N S I T Y_{i, r, t}^{F}\right)$ segíti a komparatív előny meglétét egy-egy régió-termék kombináció esetében [(1) modell]. Érdekes módon a sürüség hatásának a meglévő és az új termékekre való felbontásakor azt látjuk, hogy a hazai és külföldi tulajdonú vállalatok által exportált $\left[\left(1-X R C A_{i, r, t}^{\text {ind }}\right) \times X D E N S I T Y_{i, r, t}^{D}\right.$ és 
$\left(1-X R C A_{i, r, t}^{\text {ind }}\right) \times \operatorname{XDENSITY~}_{i, r, t}^{F}$, illetve a hazaiak által importált termékek sűrüsége $\left[\left(1-X R C A_{i, r, t}^{\text {ind }}\right) \times I M P D E N S I T Y_{i, r, t}^{D, R E S}\right]$ pozitív kapcsolatban van az új exporttermékek megjelenésével, míg a már a régiókban jelen lévő termékekre nem találunk hatást [(2) modell].

\section{3. táblázat}

A hazai, illetve külföldi tulajdonú vállalatok terméksűrüsége és az exporttermékekben jelentkező komparatív előny kapcsolata

\begin{tabular}{|c|c|c|}
\hline & (1) & (2) \\
\hline & összes $\left(X R C A_{i, r, t+1}^{\text {ind }}\right)$ & összes $\left(X R C A_{i, r, t+1}^{\text {ind }}\right)$ \\
\hline $\log$ POPDENS $_{r, t}$ & $\begin{array}{l}-0,005 \\
(-1,71)\end{array}$ & $\begin{array}{l}-0,005 \\
(-1,63)\end{array}$ \\
\hline$X R C A_{i, r, t}^{\text {ind }}$ & $\begin{array}{l}0,659^{* * *} \\
(66,04)\end{array}$ & $\begin{array}{l}0,635^{\star * *} \\
(44,74)\end{array}$ \\
\hline$X D E N S I T Y_{i, r, t}^{D}$ & $\begin{array}{l}0,020^{* * *} \\
(4,19)\end{array}$ & \\
\hline$X D E N S I T Y_{i, r, t}^{F}$ & $\begin{array}{l}0,023^{* * *} \\
(5,11)\end{array}$ & \\
\hline$I M P D E N S I T Y_{i, r, t}^{D, R E S}$ & $\begin{array}{r}0,007 \\
(1,60)\end{array}$ & \\
\hline$I M P D E N S I T Y_{i, r, t}^{F, R E S}$ & $\begin{array}{r}0,006 \\
(1,22)\end{array}$ & \\
\hline$X R C A_{i, r, t}^{i n d} \times X D E N S I T Y_{i, r, t}^{D}$ & & $\begin{array}{r}0,013 \\
(0,64)\end{array}$ \\
\hline$\left(1-X R C A_{i, r, t}^{\text {ind }}\right) \times X D E N S I T Y_{i, r, t}^{D}$ & & $\begin{array}{l}0,017^{\star * *} \\
(5,18)\end{array}$ \\
\hline$X R C A_{i, r, t}^{\text {ind }} \times X D E N S I T Y_{i, r, t}^{F}$ & & $\begin{array}{r}0,036 \\
(1,64)\end{array}$ \\
\hline$\left(1-X R C A_{i, r, t}^{i n d}\right) \times X D E N S I T Y_{i, r, t}^{F}$ & & $\begin{array}{l}0,019^{* * *} \\
(4,74)\end{array}$ \\
\hline$X R C A_{i, r, t}^{\text {ind }} \times I M P D E N S I T Y_{i, r, t}^{D, R E S}$ & & $\begin{array}{l}-0,006 \\
(-0,55)\end{array}$ \\
\hline$\left(1-X R C A_{i, r, t}^{i n d}\right) \times I M P D E N S I T Y_{i, r, t}^{D, R E S}$ & & $\begin{array}{l}0,009^{* *} \\
(2,91)\end{array}$ \\
\hline$X R C A_{i, r, t}^{\text {ind }} \times I M P D E N S I T Y_{i, r, t}^{F, R E S}$ & & $\begin{array}{r}0,000 \\
(0,04)\end{array}$ \\
\hline$\left(1-X R C A_{i, r, t}^{i n d}\right) \times I M P D E N S I T Y_{i, r, t}^{F, R E S}$ & & $\begin{array}{r}0,008 \\
(1,95)\end{array}$ \\
\hline Periódus-fixhatás & igen & igen \\
\hline Termék-fixhatás (SITC2) & igen & igen \\
\hline Megfigyelések száma & 174150 & 174150 \\
\hline Kiigazított $R^{2}$ & 0,455 & 0,455 \\
\hline
\end{tabular}




\section{A 3. táblázat folytatása}

\begin{tabular}{|c|c|c|}
\hline & (3) & (4) \\
\hline & hazai $\left(X R C A_{i, r, t+1}^{D, \text { ind }}\right)$ & hazai $\left(X R C A_{i, r, t+1}^{D, \text { ind }}\right)$ \\
\hline $\log P O P D E N S_{r, t}$ & $\begin{array}{r}0,003 \\
(0,64)\end{array}$ & $\begin{array}{r}0,002 \\
(0,51)\end{array}$ \\
\hline$X R C A_{i, r, t}^{D, \text { ind }}$ & $\begin{array}{l}0,553^{\star \star \star *} \\
(44,76)\end{array}$ & $\begin{array}{l}0,548^{\star \star \star} \\
(29,43)\end{array}$ \\
\hline$X D E N S I T Y_{i, r, t}^{D}$ & $\begin{array}{l}0,042^{* * *} \\
(8,06)\end{array}$ & \\
\hline$X D E N S I T Y_{i, r, t}^{F}$ & $\begin{array}{l}0,014^{* *} \\
(2,75)\end{array}$ & \\
\hline$I M P D E N S I T Y_{i, r, t}^{D, R E S}$ & $\begin{array}{l}0,015^{* * *} \\
(3,82)\end{array}$ & \\
\hline$I M P D E N S I T Y_{i, r, t}^{F, R E S}$ & $\begin{array}{l}-0,008 \\
(-1,94)\end{array}$ & \\
\hline$X R C A_{i, r, t}^{D, \text { ind }} \times X D E N S I T Y_{i, r, t}^{D}$ & & $\begin{array}{l}0,081^{* * *} \\
(3,63)\end{array}$ \\
\hline$\left(1-X R C A_{i, r, t}^{D, \text { ind }}\right) \times X D E N S I T Y_{i, r, t}^{D}$ & & $\begin{array}{l}0,030^{\star * *} \\
(6,58)\end{array}$ \\
\hline$X R C A_{i, r, t}^{D, \text { ind }} \times X D E N S I T Y_{i, r, t}^{F}$ & & $\begin{array}{l}-0,041 \\
(-1,55)\end{array}$ \\
\hline$\left(1-X R C A_{i, r, t}^{D, \text { ind }}\right) \times X D E N S I T Y_{i, r, t}^{F}$ & & $\begin{array}{l}0,018^{\star * *} \\
(4,46)\end{array}$ \\
\hline$X R C A_{i, r, t}^{D, \text { ind }} \times I M P D E N S I T Y_{i, r, t}^{D, R E S}$ & & $\begin{array}{l}0,030^{*} \\
(2,01)\end{array}$ \\
\hline$\left(1-X R C A_{i, r, t}^{D, \text { ind }}\right) \times I M P D E N S I T Y_{i, r, t}^{D, R E S}$ & & $\begin{array}{l}0,011^{* * *} \\
(4,10)\end{array}$ \\
\hline$X R C A_{i, r, t}^{D, \text { ind }} \times I M P D E N S I T Y_{i, r, t}^{F, R E S}$ & & $\begin{array}{l}-0,046^{* * *} \\
(-3,43)\end{array}$ \\
\hline$\left(1-X R C A_{i, r, t}^{D, \text { ind }}\right) \times I M P D E N S I T Y_{i, r, t}^{F, R E S}$ & & $\begin{array}{r}0,001 \\
(0,38)\end{array}$ \\
\hline Periódus-fixhatás & igen & igen \\
\hline Termék-fixhatás (SITC2) & igen & igen \\
\hline Megfigyelések száma & 174150 & 174150 \\
\hline Kiigazított $R^{2}$ & 0,333 & 0,334 \\
\hline
\end{tabular}

(6)

külföldi $\left(X R C A_{i, r, t+1}^{F, \text { ind }}\right)$ külföldi $\left(X R C A_{i, r, t+1}^{F, \text { ind }}\right)$

$\log$ POPDENS

$\begin{array}{cc}0,000 & 0,000 \\ (0,04) & (0,01) \\ 0,647^{\star * \star} & 0,620^{\star * *} \\ (55,54) & (33,00)\end{array}$

$X R C A_{i, r, t}^{F, \text { ind }}$

$(55,54)$

$(33,00)$ 
A 3. táblázat folytatása

(5)

(6)

\begin{tabular}{|c|c|c|}
\hline & \\
\hline & külföldi $\left(X R C A_{i, r, t+1}^{F, \text { ind }}\right)$ & külföldi $\left(X R C A_{i, r, t+1}^{F, \text { ind }}\right)$ \\
\hline$X D E N S I T Y_{i, r, t}^{D}$ & $\begin{array}{l}0,014^{\star *} \\
(2,78)\end{array}$ & \\
\hline$X D E N S I T Y_{i, r, t}^{F}$ & $\begin{array}{l}0,028^{* * *} \\
(5,48)\end{array}$ & \\
\hline$I M P D E N S I T Y_{i, r, t}^{D, R E S}$ & $\begin{array}{r}0,008 \\
(1,83)\end{array}$ & \\
\hline$I M P D E N S I T Y_{i, r, t}^{F, R E S}$ & $\begin{array}{r}0,010 \\
(1,81)\end{array}$ & \\
\hline$X R C A_{i, r, t}^{F, \text { ind }} \times X D E N S I T Y_{i, r, t}^{D}$ & & $\begin{array}{r}0,020 \\
(0,92)\end{array}$ \\
\hline$\left(1-X R C A_{i, r, t}^{F, \text { ind }}\right) \times X D E N S I T Y_{i, r, t}^{D}$ & & $\begin{array}{l}0,011^{\star *} \\
(3,35)\end{array}$ \\
\hline$X R C A_{i, r, t}^{F, \text { ind }} \times X D E N S I T Y_{i, r, t}^{F}$ & & $\begin{array}{r}0,031 \\
(1,14)\end{array}$ \\
\hline$\left(1-X R C A_{i, r, t}^{F, \text { ind }}\right) \times X \operatorname{DENSITY} Y_{i, r, t}^{F}$ & & $\begin{array}{l}0,025^{* * *} \\
(6,19)\end{array}$ \\
\hline$X R C A_{i, r, t}^{F, \text { ind }} \times I M P D E N S I T Y_{i, r, t}^{D, R E S}$ & & $\begin{array}{l}-0,010 \\
(-0,81)\end{array}$ \\
\hline$\left(1-X R C A_{i, r, t}^{F, \text { ind }}\right) \times I M P D E N S I T Y_{i, r, t}^{D, R E S}$ & & $\begin{array}{l}0,010^{* *} \\
(3,09)\end{array}$ \\
\hline$X R C A_{i, r, t}^{F, \text { ind }} \times I M P D E N S I T Y_{i, r, t}^{F, R E S}$ & & $\begin{array}{c}0,004 \\
(0,26)\end{array}$ \\
\hline$\left(1-X R C A_{i, r, t}^{F, \text { ind }}\right) \times \operatorname{IMPDENSITYY_{i,r,t}^{F,RES}}$ & & $\begin{array}{l}0,011^{\star *} \\
(2,79)\end{array}$ \\
\hline Periódus-fixhatás & igen & igen \\
\hline Termék-fixhatás (SITC2) & igen & igen \\
\hline Megfigyelések száma & 174150 & 174150 \\
\hline Kiigazított $R^{2}$ & 0,437 & 0,438 \\
\hline
\end{tabular}

Megjegyzés: standardizált béta együtthatók; $t$-értékek zárójelben.

${ }^{*} p<0,05,{ }^{* *} p<0,01,{ }^{* *} p<0,001$.

Forrás: saját szerkesztés.

A hazai vállalatok által elóállított termékek diverzifikációját elemezve, az látszik, hogy azt erősebben befolyásolja a hazai vállalatok termékeinek exportsürüsége (XDENSITY $\left.{ }_{i, r, t}^{D}\right)$, mint a külföldieké (XDENSITY $\left.Y_{i, r, t}^{F}\right)$ [(3) modell]. Emellett az importsürüség is segíti a befogadó gazdaság diverzifikációját, amennyiben a hazai vállalatok importálnak (IMPDENSITY $Y_{i, r, t}^{D, R E S}$ ). A befogadó gazdaságban termelt termékek sürüsége egyaránt hozzájárul ezeknek a termékeknek a fennmaradásához $\left(X R C A_{i, r, t}^{D, \text { ind }} \times X D E N S I T Y_{i, r, t}^{D}\right)$, illetve az új termékek megjelenéséhez $\left[\left(1-X R C A_{i, r, t}^{D, \text { ind }}\right) \times I M P D E N S I T Y_{i, r, t}^{D, R E S}\right][(4)$ modell]. Az is látszik viszont, hogy a külföldi 
tulajdonú vállalatok exporttermékeinek sürüsége hasonlóan fontos hajtóereje az új termékek megjelenésének $\left[\left(1-X R C A_{i, r, t}^{D, \text { ind }}\right) \times X_{\text {DENSITY }}^{F}{ }_{i, r}\right]$. Az importra vonatkozóan egyrészt az látszik, hogy a hazai vállalatok által importált termékek sürüsége és az új exporttermékek megjelenése között erősen szignifikáns a kapcsolat $\left[\left(1-X R C A_{i, r, t}^{D, \text { ind }}\right) \times\right.$ $\left.\times I M P D E N S I T Y_{i, r, t}^{D, R E S}\right]$, de még az exporttermékek fennmaradásával is gyengén szigni-

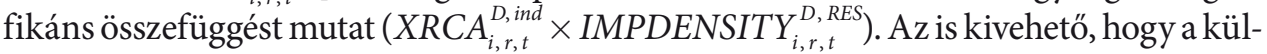
földi tulajdonú vállalatok importtermék-sűrüsége erősen negatív hatást gyakorol a befogadó gazdaság exporttermékeinek fennmaradására $\left(X R C A_{i, r, t}^{D, \text { ind }} \times \operatorname{IMPDENSITY} Y_{i, r, t}^{F, R E S}\right)$, ami egyfajta helyettesítésre, kiszorító hatásra utal.

Ami a külföldi tulajdonú vállalatok exporttermékeit illeti, eredményeink szintén azt mutatják, hogy a hazai és a külföldi terméksürüség pozitívan hat a komparatív elöny meglétére $\left(X_{D E N S I T Y}{ }_{i, r, t}^{D}\right.$ és $\left.X D E N S I T Y_{i, r, t}^{F}\right)[(5)$ modell]. Megkülönböztetve az új termékek megjelenését és a meglévők fennmaradását, azt látjuk, hogy a külföldi tulajdonú vállalatok által exportált termékeknél a termékszerkezet stabilitását nem segíti a külföldiek exporttermékeinek sürüsége $\left(X R C A_{i, r, t}^{F, \text { ind }} \times\right.$ $\left.\times X_{\text {DENSITY }}^{F}{ }_{i, r}, t\right)[(6)$ modell]. Ez összhangban van azzal, hogy a külföldi tulajdonú vállalatok a termelés során kevésbé hagyatkoznak a terméksürűség által kínált újrakombinálási lehetőségekre. Ezzel szemben az új termékek megjelenését mindkét vállalatcsoport termékeinek sürüsége egyaránt segíti $\left[\left(1-X R C A_{i, r, t}^{F, \text { ind }}\right) \times X D E N S I T Y_{i, r, t}^{F}\right.$ és $\left.\left(1-X R C A_{i, r, t}^{F, \text { ind }}\right) \times X D E N S I T Y_{i, r, t}^{D}\right]$. A kapcsolódó import szintén segíti a külföldi tulajdonú vállalatok exportjának diverzifikációját. Ez egyaránt igaz a hazai vállalatok kapcsolódó importsürüségére $\left[\left(1-X R C A_{i, r, t}^{F, \text { ind }}\right) \times I M P D E N S I T Y_{i, r, t}^{D, R E S}\right]$, valamint a külföldi tulajdonúakéra $\left[\left(1-X R C A_{i, r, t}^{F, \text { ind }}\right) \times I M P D E N S I T Y_{i, r, t}^{F, R E S}\right]$. Ezek az eredmények azt mutatják, hogy az import egy olyan csatorna, amelyen keresztül a külföldi tulajdonú vállalatok a diverzifikációhoz szükséges képességekhez juthatnak. Ez pedig független attól, hogy ők maguk importálnak, vagy pedig vélhetően beszállítói láncokon keresztül, a befogadó gazdaság importja formájában jutnak hozzá ezekhez a képességekhez.

\section{Összegzés}

Ezzel a tanulmánnyal egyrészt az a célunk, hogy a hazai térségek esetében is megmutassuk a kapcsolódó diverzifikáció müködését a helyi gazdaság szerkezetének időbeli változása során. Másrészt szeretnénk jobban megérteni a régión kívül hozzáférhető képességek szerepét a regionális diverzifikációban. Ezt az elemzés során a külföldi-hazai tulajdon és az import szempontjainak figyelembevételével törekedtünk elérni, amelyek egyúttal lényeges dimenziói is a hazai gazdaságnak. E célok elérése érdekében mintaszelekciót követően 75 kistérség és 775 külkereskedelmi termék esetében vizsgáltuk a kapcsolódó termékek jelenlétének szerepét az exporttermék-szerkezet időbeli változásában 2000 és 2011 között. Az egyes termékek kapcsolódásának mértékét az országok közötti kereskedelmi termékáramlások alapján alkotott hálózat segítségével mértük.

A kutatás legfontosabb eredményei három pontban foglalhatók össze. Egyrészt kimutatható, hogy a hazai térségek exportszerkezetének időbeli változására hatással 
van a már meglévő export-, illetve importszerkezet, vagyis a kapcsolódó termékek jelenléte. Ez tehát egy olyan szempont, amelyet a regionális gazdaságfejlesztési stratégia kialakításakor érdemes figyelembe venni. Másrészt, az exportszerkezet stabilitásához különösen a hazai vállalatok által előállított exporttermékek sürüsége járul hozzá. Ha a befogadó gazdaság képességbázisát tekintjük a helyben elérhető képességek halmazának, akkor ez arra is felhívja a figyelmet, hogy a külföldi tulajdonú vállalatok meglévő tevékenységeik fennmaradása szempontjából kevésbé beágyazottak a régiók gazdaságába, kevésbé függnek attól. Végül az új exporttermékek megjelenését a külföldi tulajdonú és a hazai vállalatok által létrehozott export esetében is segíti a másik kapcsolódó termékeinek jelenléte. Az exporthoz kapcsolódó import hasonlóképpen föleg az új termékek megjelenésében játszik szerepet. Lényeges, hogy a külföldi tulajdonú vállalatok által a régióban meghonosított új termékeket a hazai vállalatok kapcsolódó importja is segíti. Az új termékek megjelenése azért fontos, mert a térségek hosszú távú sikerességét érdemben befolyásolja, hogy képesek-e új tevékenységek megjelenésén keresztül bővíteni a helyi gazdaság változatosságát.

Ezeket az eredményeket fontos lépésnek tartjuk a hazai régiók gazdaságának jobb megértése szempontjából, azonban elemzésünk természetszerúen rendelkezik korlátokkal, amelyekben a kutatatás folytatásának lehetőségét és szükségességét látjuk. Egyrészt elemzésünkben nem tudtuk megvizsgálni a szolgáltatásokban megjelenő diverzifikációt. A feldolgozóiparra korlátozott vizsgálatot ennek ellenére lényegesnek tartjuk, mert a feldolgozóipari termékek jelentősége a hazai exportszerkezetben továbbra is nagy (Antalóczy [2012]), a fővároson kívül a feldolgozóipar a beáramló külföldi működőtőke kiemelt célpontja, illetve a feldolgozóipari termelésben egyre nagyobb szerepet kapnak a szolgáltatások (Szalavetz [2002]). Ezeknek a szolgáltatásoknak egy hányada, különösen a fővároson kívül, erősen kapcsolódik a helyi feldolgozóipari vállalatokhoz, így a feldolgozóipar növekedése és diverzifikációja együtt mozog a kapcsolódó szolgáltató iparágakkal. A szakirodalom alapján arra is számíthatunk, hogy a feldolgozóiparhoz képest a szolgáltatásokban nagyobb a gyengébben kapcsolódó iparágak jelentősége a növekedésben és a diverzifikációban (Bishop-Gripaios [2010]), ennek tesztelésére azonban ebben a kutatásban nem tudtunk vállalkozni.

Másrészt vizsgálatunk 2011-gyel zárul. Az azóta eltelt időszakban - különösen egyes térségek hazai vállalatai esetében - feljebb lépés történt az előállított termékek minőségében, hozzáadott értékében, illetve az újraiparosodás folyamatán keresztül lassan változik a végzett tevékenységek térbeli eloszlása és tartalma is (Lengyel I. és szerzötársai [2016], [2017], Nagy-Lengyel [2016]). Ez azonban vélhetően nem befolyásolja az itt bemutatott eredményeket, amelyek a diverzifikáció tényét érintik, a diverzifikáció tartalmát nem. Éppen ebben látjuk a kutatás folytatásának fontos irányát, amennyiben kérdés például, hogy vajon a hazai vállalatok az import, illetve a külföldi tulajdonú vállalatok jelenléte révén képessé válnak-e komplexebb termékek elöállítására. A helyi gazdaság komplexitásának ilyen módon való megváltozása, annak térbeli eloszlása lényeges kérdés. Mivel a helyi képességbázis nagysága a szakirodalom alapján viszonylag állandó, és jellemző az egyes régiókra, az is látszik, hogy a régiók sikeressége nemcsak az új tevékenységek megjelenésének tényétől, de azok tartalmától is függ. Ha 
a kapcsolódó regionális diverzifikáció révén egy régió a terméktér perifériáján erősíti meg a jelenlétét, az akadályozhatja a feljebb lépést nagyobb hozzáadott értéket képviselő és komplexebb termékek felé, ilyen módon pedig a régió bezáródásához vezethet.

\section{Hivatkozások}

AlCÁCER, J.-Chung, W. [2007]: Location strategies and knowledge spillovers. Management Science, Vol. 53. No. 5. 760-776. o. https://doi.org/10.1287/mnsc.1060.0637.

AlmeidA, P. [1996]: Knowlegde sourcing by foreign multinationals: patent citation analysis in the US semiconductor industry. Strategic Management Journal, Vol. 17. No. S2. 155-165. o. https://doi.org/10.1002/smj.4250171113.

ANTALóczy KaTALin [2012]: Beágyazódás a globális értékláncokba - két évtized külkereskedelmi folyamatai Magyarországon. Külgazdaság, 56. évf. 11-12. sz. 29-61. o.

Antalóczy Katalin-Sass Magdolna [2011]: Kis- és közepes méretű vállalatok nemzetköziesedése - elmélet és empíria. Külgazdaság, 55. évf. 9-10. sz. 22-33. o.

Arzaghi, M.-Henderson, J. V. [2008]: Networking off madison avenue. The Review of Economic Studies, Vol. 75. No. 4. 1011-1038. o. https://doi.org/10.1111/j.1467-937x.2008. 00499.x.

Balland, P.-A.-RigBy, D. [2017]: The geography of complex knowledge. Economic Geography, Vol. 93. No. 1. 1-23. o. https://doi.org/10.1080/00130095.2016.1205947.

BARNEY, J. [1991]: Firm resources and sustained competitive advantage. Journal of Management, Vol. 17. No. 1. 99-120. o. https://doi.org/10.1177/014920639101700108.

BARTA Györgyi [2005]: The Role of Foreign Direct Investment in the Spatial Restructuring of Hungarian Industry. Megjelent: Barta Györgyi-G. Fekete Éva-Szörényiné Kukorelli Irén-Timár Judit (szerk.): Hungarian Spaces and Places: Patterns of Transition. Centre for Regional Studies, Pécs, 143-160. o.

BÉKÉs GÁbor-Mura Közy Balázs [2016]: Beszállítói termékek a magyar feldolgozóiparban. Közgazdasági Szemle, 63. évf. 10. sz. 1046-1073. o. https://doi.org/10.18414/ ksz.2016.10.1046.

BéкÉs GÁbor-Kleinert, J.-Toubal, F. [2009]: Spillovers from multinationals to heterogeneous domestic firms: evidence from Hungary. The World Economy, Vol. 32. No. 10. 1408-1433. o. https://doi.org/10.1111/j.1467-9701.2009.01179.x.

BÉKÉs GÁBOR-HALPERN LÁszLó-MuRAKÖZy BALÁzs [2013]: Külkereskedelem és a vállalatok közötti különbségek. Közgazdasági Szemle, 60. évf. 1. sz. 1-24. o.

BenaceK, V.-Gronicki, M.-Holland, D.-Sass Magdolna [2000]: The determinants and impact of FDI in Central and Eastern Europe: a comparison of survey and econometric evidence. Transnational Corporations, Vol. 9. No. 3. 163-212. o.

Bishop, P.-Gripaios, P. [2010]: Spatial Externalities, Relatedness and Sector Employment Growth in Great Britain. Regional Studies, Vol. 44. No. 4. 443-454. o. https:/doi. org/10.1080/00343400802508810.

Boschma, R.-CAPone, G. [2015]: Institutions and diversification: Related versus unrelated diversification in a Varieties of Capitalism framework. Research Policy, Vol. 44. No. 10. 1902-1914. o. https://doi.org/10.1016/j.respol.2015.06.013.

Boschma, R.-CA pone, G. [2016]: Relatedness and diversification in the European Union (EU-27) and European neighbourhood policy countries. Environment and Planning C: Government and Policy, Vol. 34. No. 4. 617-637. o. https://doi.org/10.1177/0263774x15614729. 
Boschma, R.-Iammarino, S. [2009]: Related Variety, Trade Linkages, and Regional Growth in Italy. Economic Geography, Vol. 85. No. 3. 289-311. o. https://doi.org/10.1111/j.19448287.2009.01034.x.

Boschma, R.-Minondo, A.-Navarro, M. [2013]: The Emergence of New Industries at the Regional Level in Spain: A Proximity Approach Based on Product Relatedness. Economic Geography, Vol. 89. No. 1. 29-51. o. https://doi.org/10.1111/j.1944-8287.2012.01170.x.

CAntwell, J.-Piscitello, L. [2005]: Recent location of foreign-owned research and development activities by large multinational corporations in the European regions: the role of spillovers and externalities. Regional Studies, Vol. 39. No. 1. 1-16. o. https://doi.org/10.10 80/0034340052000320824.

Csáfordi Zsolt-Lőrincz LÁszló-Lengyel Balázs-Kiss Károly Miklós [2020]: Productivity spillovers through labor flows: productivity gap, multinational experience and industry relatedness. The Journal of Technology Transfer, Vol. 45. No. 1. 86-121. o. https:// doi.org/10.1007/s10961-018-9670-8.

Elekes Zoltán [2016]: A regionális növekedés új tényezői az evolúciós gazdaságföldrajzi kutatásokban. A változatosság és a technológiai közelség. Közgazdasági Szemle, 63. évf. 3. sz. 307-329. o. https://doi.org/10.18414/ksz.2016.3.307.

Elekes Zoltán [2017]: A terméktér időbeli változása. Megjelent: Farkas Beáta-Pelle Anita (szerk.): Várakozások és gazdasági interakciók. JATEPress, Szeged, 239-253. o.

Elekes Zoltán-Boschma, R.-Lengyel Balázs [2019]: Foreign-owned firms as agents of structural change in regions. Regional Studies, Vol. 53. No. 11. 1603-1613. o. https://doi. org/10.1080/00343404.2019.1596254.

Feenstra, R. C.-Lipsey, R. E.-Deng, H.-Ma, A. C.-Mo, H. [2005]: World trade flows: 19622000. NBER Working Paper, 11040. https://doi.org/10.3386/w11040.

Greene, W. H. [2008]: Econometric Analysis (Sixth Edition). Prentice Hall, Upper Saddle River.

Gyurkovics János-VAs Zsófia [2016]: Tudásáramlás és tanulás egy hagyományos iparágban. Vezetéstudomány, 47. évf. 12. sz. 25-37. o. https://doi.org/10.14267/ veztud.2016.12.03.

Halpern LÁszló-Muraközy Balázs [2007]: Does distance matter in spillover? The Economics of Transition, Vol. 15. No. 4. 781-805. o. https://doi.org/10.1111/j.14680351.2007.00308.x.

HALPERn LÁSZló-Muraközy BALÁzs [2010]: Innováció és vállalati teljesítmény Magyarországon. Közgazdasági Szemle, 57. évf. 4. sz. 293-317. o.

Halpern LÁszló-Koren Miklós-Szeidl Ádám [2015]: Imported inputs and productivity. American Economic Review, Vol. 105. No. 12. 3660-3703. o. https://doi.org/10.1257/ aer.20150443.

Hausmann, R.-Klinger, B. [2007]: The structure of the product space and the evolution of comparative advantage. CID Working Paper, No. 146.

Hidalgo, C. A.-Hausmann, R. [2009]: The building blocks of economic complexity. Proceedings of the National Academy of Sciences, Vol. 106. No. 26. 10 570-10 575. o. https:// doi.org/10.1073/pnas.0900943106.

Hidalgo, C. A.-Klinger, B.-Barabási, A. L.-Hausmann, R. [2007]: The product space conditions the development of nations. Science, Vol. 317. No. 5837. 482-487. o. https://doi. org/10.1126/science.1144581.

IAMMARINO, S.-MCCANN, P. [2013]: Multinationals and economic geography. Location, technology and innovation. Edward Elgar, Cheltenham-Northampton. 
Jacomy, M.-Venturini, T.-Heymann, S.-Bastian, M. [2014]: ForceAtlas2, a continuous graph layout algorithm for handy network visualization designed for the Gephi software. PLOS One, Vol. 9. No. 6. e98679. https://doi.org/10.1371/journal.pone.0098679.

Jakoвi Ákos-Lengyel Balázs [2014]: Egy online közösségi háló offline földrajza, avagy a távolság és a méret szerepének magyar empíriái. Tér és Társadalom, 28. évf. 1. sz. 40-61. o. https://doi.org/10.17649/tet.28.1.2590.

Javorcik, B. S.-Lo Turco, A.-Maggioni, D. [2018]: New and Improved: Does FDI Boost Production Complexity in Host Countries? The Economic Journal, Vol. 128. No. 614. 2507-2537. o. https://doi.org/10.1111/ecoj.12530.

JuHÁsz SÁNDOR [2019]: Spinoffs and tie formation in cluster knowledge networks. Small Business Economics, https://oi.org/10.1007/s11187-019-00235-9.

KLePper, S. [2007]: Disagreements, spinoffs, and the evolution of Detroit as the capital of the US automobile industry. Management Science, Vol. 53. No. 4. 616-631. o. https://doi. org/10.1287/mnsc.1060.0683.

Kondor Péter-Koren Miklós-PÁL Jenő-Szeidl Ádám [2014]: Cégek kapcsolati hálózatainak gazdasági szerepe. Közgazdasági Szemle, 61. évf. 11. sz. 1341-1360. o.

Lawson, C. [1999]: Towards a competence theory of the region. Cambridge Journal of Economics, Vol. 23. No. 2. 151-166. o. https://doi.org/10.1093/cje/23.2.151.

LEAmer, E. E. [1984]: Sources of International Comparative Advantage, Theory and Evidence. MIT Press, Cambridge-London.

Lengyel Balázs-JAковi Ákos [2016]: Online social networks, location, and the dual effect of distance from the centre. Journal of Economic and Social Geography, Vol. 107. No. 3 298-315. o. https://doi.org/10.1111/tesg.12150.

Lengyel Balázs-Sebestyén Tamás-Leydesdorff, L. [2015]: Challenges for regional innovation policies in Central and Eastern Europe: spatial concentration and foreign control of US patenting. Science and Public Policy, Vol. 42. No. 1. 1-14. o. https://doi. org/10.1093/scipol/sct087.

Lengyel ImRe-SZaKálné Kanó Izabella-VAs Zsófia-Lengyel Balázs [2016]: Az újraiparosodás térbeli kérdőjelei Magyarországon. Közgazdasági Szemle, 63. évf. 6. sz. 615-646. o. https://doi.org/10.18414/ksz.2016.6.615.

Lengyel Imre-Vas Zsófia-Szakálné Kanó Izabella-Lengyel Balázs [2017]: Spatial differences of reindustrialization in a post-socialist economy: manufacturing in the Hungarian counties. European Planning Studies, Vol. 25. No. 8. 1416-1434. o. https://doi.org/ 10.1080/09654313.2017.1319467.

Lőrincz László-Kiss Károly Miklós-Elekes Zoltán-Csáfordi Zsolt-Lengyel BALÁzs [2019]: Az iparágak közti hasonlóság mérésének hálózati módszerei és relevanciájuk a gazdaságfejlesztésben Közgazdasági Szemle, 66. évf. 1. sz. 22-52. o. https://doi. org/10.18414/ksz.2019.1.22.

Nagy BenedeK-Lengyel Imre [2016]: A feldolgozóipar szerkezetváltása Magyarországon 2008 és 2014 között. Külgazdaság, 60. évf. 9-10. sz. 3-27. o.

Neffke, F. [2019]: The value of complementary co-workers. Science Advances, Vol. 5. No. 12. https://doi.org/10.1126/sciadv.aax3370.

Neffke, F.-Henning, M. [2013]: Skill relatedness and firm diversification. Strategic Management Journal, Vol. 34. No. 3. 297-316. o. https://doi.org/10.1002/smj.2014.

Neffke, F.-Henning, M.-Boschma, R. [2011]: How Do Regions Diversify over Time? Industry Relatedness and the Development of New Growth Paths in Regions. Economic Geography, Vol. 87. No. 3. 237-265. o. https://doi.org/10.1111/j.1944-8287.2011.01121.x. 
Neffke, F.-Hartog, M.-Boschma, R. A.-Henning, M. [2018]: Agents of Structural Change: The Role of Firms and Entrepreneurs in Regional Diversification. Economic Geography, Vol. 94. No. 1. 23-48. o. https://doi.org/10.1080/00130095.2017.1391691.

Nölke, A.-Vliegenthart, A. [2009]: Enlarging the varieties of capitalism: The emergence of dependent market economies in East Central Europe. World Politics, Vol. 61. No. 4. 670-702. o. https://doi.org/10.1017/s0043887109990098.

PAVlíneK, P.-ŽížAlovÁ, P. [2016]: Linkages and spillovers in global production networks: firm-level analysis of the Czech automotive industry. Journal of Economic Geography, Vol. 16. No. 2. 331-363. o. https://doi.org/10.1093/jeg/lbu041.

Penrose, E. T. [1959]: The theory of the growth of the firm. Blackwell, Oxford.

RadoseviC, S. [2002]: Regional innovation systems in Central and Eastern Europe: determinants, organizers and alignments. The Journal of Technology Transfer, Vol. 27. No. 1. 87-96. o.

RESMini, L. [2007]: Regional patterns of industry location in transition countries: Does economic integration with the European Union matter? Regional Studies, Vol. 41. No. 6. 747-764. o. https://doi.org/10.1080/00343400701281741.

RoDRIK, D. [1992]: Making sense of the Soviet trade shock in Eastern Europe: a framework and some estimates. NBER Working Paper, 4112. https://doi.org/10.3386/w4112.

Sass Magdolna [2003]: Competitiveness and economic policies related to foreign direct investment. Strategic Analysis Division Working Paper, No. 3. Hungarian Ministry of Finance, http://pdc.ceu.hu/archive/00002569/01/3_eng_040223.pdf.

Sebestyén Tamás-Varga Attila [2013]: Research productivity and the quality of interregional knowledge networks. Annals of Regional Science, Vol. 51. No. 1. 155-189. o. https:// doi.org/10.1007/s00168-012-0545-X.

Szalavetz Andrea [2002]: „Új gazdaság”-jelenségek. A feldolgozóipar tercierizálódása. Külgazdaság, 46. évf. 12. sz. 4-17. o.

SzANyi Miklós [2010]: A dualitás kérdése a rendszerváltást követő gazdasági fejlődésben. Competitio, 9. évf. 1. sz. 71-90. o. https://doi.org/10.21845/comp/2010/1/4.

TeEce, D. J. [1982]: Towards an economic theory of the multiproduct firm. Journal of Economic Behavior \& Organization, Vol. 3. No. 1. 39-63. o. https://doi.org/10.1016/01672681(82)90003-8.

Teece, D. J.-Pisano, G.-Shuen, A. [1997]: Dynamic Capabilities and Startegic Management. Startegic Management Journal, Vol. 18. No. 7. 509-533. o. https://doi.org/10.1002/(sici)10970266(199708)18:7<509::aid-smj882>3.0.co;2-z.

Varga Attila-Sebestyén Tamás-Szabó Norbert-Szerb László [2020]: Estimating the economic impacts of knowledge network and entrepreneurship development in smart specialization policy. Regional Studies, Vol. 54. No. 1. 48-59. o. https://doi.org/10.1080/0034 3404.2018.1527026.

VAs Zsófia-Lengyel ImRe-Szakálné Kanó Iza Bella [2015]: Regionális klaszterek és agglomerációs előnyök: Feldolgozóipar a magyar városrégiókban. Tér és Társadalom, 29. évf. 3. sz. 49-72. o. https://doi.org/10.17649/tet.29.3.2697. 